\title{
Arming Immune Cells for Battle: A Brief Journey through the Advancements of T and NK Cell Immunotherapy
}

\author{
Philipp Wendel ${ }^{1,2,+}{ }^{\oplus}$, Lisa Marie Reindl ${ }^{1,2,+}{ }^{-}$, Tobias Bexte ${ }^{1,2}$, Leander Künnemeyer ${ }^{1,2}$, Vinzenz Särchen ${ }^{3}{ }^{-}$, \\ Nawid Albinger ${ }^{1,2}$, Andreas Mackensen ${ }^{4}$, Eva Rettinger ${ }^{1}$, Tobias Bopp ${ }^{5,6,7,8}$ and Evelyn Ullrich 1,2,8,9,*(1)
}

1 Children's Hospital, Division for Stem Cell Transplantation, Immunology and Intensive Care Medicine, Goethe-University Frankfurt, 60590 Frankfurt am Main, Germany; philipp.wendel@kgu.de (P.W.); lisamarie.reindl@kgu.de (L.M.R.); tobias.bexte@kgu.de (T.B.); leander.kuennemeyer@kgu.de (L.K.); nawid.albinger@kgu.de (N.A.); eva.rettinger@kgu.de (E.R.)

2 Experimental Immunology, Goethe-University Frankfurt, 60590 Frankfurt am Main, Germany

3 Institute for Experimental Cancer Research in Pediatrics, Goethe-University Frankfurt, 60528 Frankfurt am Main, Germany; v.saerchen@kinderkrebsstiftung-frankfurt.de

4 Department of Medicine 5, University Hospital Erlangen, University of Erlangen-Nuremberg, 91054 Erlangen, Germany; Andreas.Mackensen@uk-erlangen.de

5 Institute for Immunology, University Medical Center, Johannes Gutenberg-University Mainz, 55131 Mainz, Germany; boppt@uni-mainz.de

6 Research Center for Immunotherapy (FZI), University Medical Center Mainz, 55131 Mainz, Germany

7 University Cancer Center Mainz, University Medical Center, 55131 Mainz, Germany

8 German Cancer Consortium (DKTK), Partner Site Frankfurt/Mainz, 69120 Heidelberg, Germany

check for updates

Citation: Wendel, P.; Reindl, L.M.; Bexte, T.; Künnemeyer, L.; Särchen, V.; Albinger, N.; Mackensen, A.; Rettinger, E.; Bopp, T.; Ullrich, E. Arming Immune Cells for Battle: A Brief Journey through the Advancements of $\mathrm{T}$ and NK Cell Immunotherapy. Cancers 2021, 13, 1481. https://doi.org/10.3390/ cancers13061481

Academic Editor: Raquel Tarazona

Received: 21 February 2021

Accepted: 18 March 2021

Published: 23 March 2021

Publisher's Note: MDPI stays neutral with regard to jurisdictional claims in published maps and institutional affiliations.

Copyright: (c) 2021 by the authors. Licensee MDPI, Basel, Switzerland. This article is an open access article distributed under the terms and conditions of the Creative Commons Attribution (CC BY) license (https:// creativecommons.org/licenses/by/ $4.0 /)$.
9 Frankfurt Cancer Institute, Goethe-University Frankfurt, 60590 Frankfurt am Main, Germany

* Correspondence: evelyn.ullrich@kgu.de

+ Both authors share first co-authorship.

Simple Summary: This review is intended to provide an overview on the history and recent advances of $\mathrm{T}$ cell and natural killer (NK) cell-based immunotherapy. While the thymus was discovered as the origin of T cells in the 1960s, and NK cells were first described in 1975, the clinical application of adoptive cell therapies (ACT) only began in the early 1980s with the first lymphokine activated killer (LAK) cell product for the treatment of cancer patients. Over the past decades, further immunotherapies have been developed, including ACT using cytokine-induced killer (CIK) cells, products based on the NK cell line NK-92 as well as specific T and NK cell preparations. Recent advances have successfully improved the effectiveness of T, NK, CIK or NK-92 cells towards tumor-targeting antigens generated by genetic engineering of the immune cells. Herein, we summarize the promising development of ACT over the past decades in the fight against cancer.

Abstract: The promising development of adoptive immunotherapy over the last four decades has revealed numerous therapeutic approaches in which dedicated immune cells are modified and administered to eliminate malignant cells. Starting in the early 1980s, lymphokine activated killer (LAK) cells were the first ex vivo generated NK cell-enriched products utilized for adoptive immunotherapy. Over the past decades, various immunotherapies have been developed, including cytokine-induced killer (CIK) cells, as a peripheral blood mononuclear cells (PBMCs)-based therapeutic product, the adoptive transfer of specific T and NK cell products, and the NK cell line NK-92. In addition to allogeneic NK cells, NK-92 cell products represent a possible "off-the-shelf" therapeutic concept. Recent approaches have successfully enhanced the specificity and cytotoxicity of T, NK, CIK or NK-92 cells towards tumor-specific or associated target antigens generated by genetic engineering of the immune cells, e.g., to express a chimeric antigen receptor (CAR). Here, we will look into the history and recent developments of $\mathrm{T}$ and NK cell-based immunotherapy.

Keywords: NK cell; T cell; CIK cell; NK-92; cell therapy; immune therapy; CAR-T cell; CAR-NK cell 


\section{Characteristics, Target Recognition and Antitumor Functionality of $T$ and NK Cells}

Natural killer (NK) cells and T cells are key players of the immune system and utilize several defensive mechanisms to protect the body against viral infections and diseases. Their specific roles as active engagers of possible threats set them apart from the nonengaging immune system, including monocytes and B cells. Despite the fact that both cell types share the purpose of efficiently eliminating pathogen-infected or malignant cells, their target recognition and mode of action varies significantly.

Natural killer (NK) cells were first discovered in mice concurrently by Kiessling [1,2] and Herberman [3,4] in 1975 (Figure 1). The natural occurrence of killer lymphocytes has been described in splenocytes of mice that induced specific cytolytic activity against in vitro-grown mouse Moloney leukemia cells [1,2]. These naturally occurring killer cells were first called "N-cells", distinct from T cells, B cells and macrophages [3-5]. In 1986, Lanier and colleagues proposed that the term "naturally occurring cytotoxicity" should be replaced by "non-major histocompatibility complex (MHC) restricted cytotoxicity" and further termed the respective effector cells natural killer (NK) cells [6]. In the same year, Kärre and Ljunggren described the underlying mechanism of the recognition of malignantly transformed or virus-infected cells by NK cells as the "missing self-hypothesis" [7].

As a part of the innate immune system, NK cells represent a first line defense equipped with a broad repertoire of activating and inhibiting receptors, that allow target-specific recognition and controlled cytotoxic activity without prior stimulation [3,8]. In contrast to T cells, NK cells are able to rely on a highly effective mechanism called "missing selfrecognition". This mechanism allows the discrimination of healthy cells from malignant or infected cells based on the associated loss of MHC class I expression and decrease in suppressive feedback provided by MHC-interaction-based inhibitory receptors, such as killer-immunoglobulin-like receptors (KIRs) and natural killer group two molecules (e.g., NKG2A/B) [9-17]. The resulting imbalance in favor of activating signals is further complemented by the stress-associated upregulation of ligands for activating receptors, such as the lysis-triggering natural cytotoxicity receptors (NCRs) NKp30, NKp44 or NKp46 as well as NKG2D, which finally lead to activation of NK cells, modified gene expression and cytolytic activity towards the target cells [18-21]. Additionally, NK cells utilize receptorligand interactions, including the tumor necrosis factor-related apoptosis-inducing ligand (TRAIL) and the Fas ligand (FasL), to promote death receptor-induced apoptosis of the interacting target cell [13]. Furthermore, NK cells provide immune modulatory function by secreting cytokines and chemokines for further regulation of the immune response [22-24]. A detailed overview of the killing mechanism of NK cells in context of immunotherapy has recently been reported [13]. On the cellular level, NK cells are defined based on their cluster of differentiation (CD) surface receptor profile as $\mathrm{CD}^{2} 6^{+} \mathrm{CD}^{-}$lymphocytes, and two distinct subpopulations can be classified based on the surface density of CD56 and the low-affinity Fc gamma receptor III (Fc $\gamma$ RIII), also known as CD16 [22,25]. The CD56 $6^{\text {bright }}$ CD16 ${ }^{\text {dim }}$ subpopulation and their immune modulatory activity are functionally distinguishable from the $\mathrm{CD} 56^{\mathrm{dim}} \mathrm{CD} 16^{\text {bright }}$ population, which represents the NK cell subset with direct cytotoxic capacity $[26,27]$. Expression of CD16 provides NK cells the ability to synergize with the adaptive immune system by killing antibody-coated (opsonized) target cells through the antibody-dependent cell cytotoxicity (ADCC) pathway, which is not available to $T$ cells $[8,22,24,28]$.

Although the innate immune system can overcome many obstacles on its own, the role of the adaptive immune system is crucial in the second line of defense that leads to acquired immunity. 


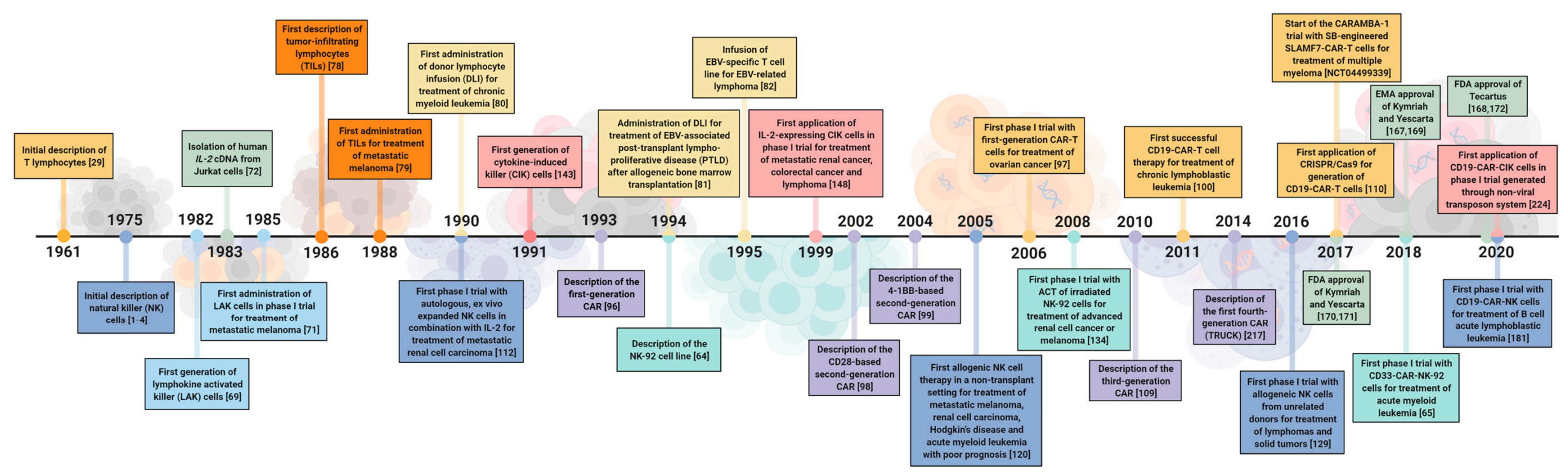

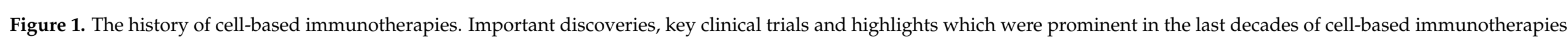

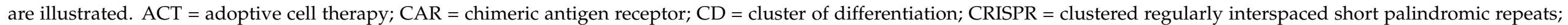

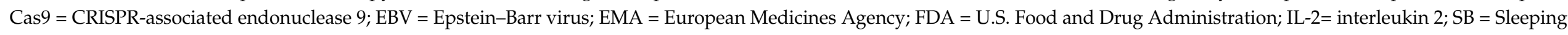
Beauty transposon/transposase system; TRUCK = T cells redirected for universal cytokine killing. 
In the 1960s, Jaques Miller first identified the thymus as the origin of $\mathrm{T}$ cells (Figure 1) [29-33]. Until that time, the thymus was considered to be a rudimentary structure and a "graveyard" for lymphocytes [34,35]. By thymus transfer experiments in neonatally thymectomized mice, Miller showed that immune function could be restored and that these mice rejected allogeneic but not donor-derived skin grafts [33], revealing the immunological function of the thymus as the origin of $\mathrm{T}$ cells and its relevance in establishing self-tolerance. Subsequent studies demonstrated that mouse lymphocytes can be classified into two distinct lineages, which are either derived from the bone marrow (B cells) or thymus (T cells) [36]. Furthermore, it has been described that $\mathrm{T}$ cells undergo mitosis upon antigen stimulation, while B cells show great proficiency at secreting antibodies but only upon interaction with the prior antigen-activated T cells [37-40]. Based on these findings, the earliest function for $\mathrm{T}$ cells was described as that of $\mathrm{B}$ cell helpers, leading to the term $\mathrm{T}$ helper (TH) cells.

Since the discovery of their potent cytotoxic capabilities, $\mathrm{T}$ cells have been the focus of various immunotherapeutic approaches. Their highly specific recognition of malignant or infected cells is based on the interaction of a compatible membrane-bound $\mathrm{T}$ cell receptor (TCR) with short peptide motifs related to tumor-associated antigens (TAA) or viral proteins that are presented on the MHC or human leukocyte antigens (HLAs) by antigen presenting cells as well as other nucleated cells [41-43]. The resulting mode of action after antigeninteraction is heavily dependent on the $\mathrm{T}$ cell subtype.

In the early stages of $\mathrm{T}$ cell development, clonal TCRs are formed after rearrangement of the $\alpha, \beta, \gamma$ and $\delta$ chains, followed by a TCR-mediated positive selection. This process results in maturation of $\mathrm{CD} 4^{+} \mathrm{T}$ helper cells and $\mathrm{CD} 8^{+}$cytotoxic $\mathrm{T}$ cells [43-46]. Subsequent negative selection eliminates $\mathrm{T}$ cells that recognize self-antigens with high specificity prior to entrance into the circulatory system to prevent potential autoimmune reactions $[43,47,48]$. The further characterization of mature T cell subsets is based on their phenotype after initial activation by costimulatory receptors as well as secreted cytokines. In general, the heterogenic $\alpha \beta$-TCR T cell population is composed of regulatory $\mathrm{CD} 4^{+}$or $\mathrm{CD} 8^{+} \mathrm{T}$ cells (Tregs), which modulate immune responses by several mechanisms (reviewed in Ulges et al. [49]), memory $\mathrm{T}$ cells that ensure a fast immune reaction after repeated contact with their specific antigen as well as $\mathrm{CD} 4^{+} \mathrm{TH}$ cells, that contribute to the immune response through additional stimulation of $\mathrm{CD}^{+}$cytotoxic $\mathrm{T}$ lymphocytes (CTLs), which exert the main cytotoxic activity to eliminate infected or malignant cells $[17,42,43,50-54]$. Further description of the $\mathrm{T}$ cell phenotypes can be found in a recently published review article [43]. Concurrently with the maturation of the $\mathrm{T}$ cell subtypes, natural killer $\mathrm{T}$ cells (NKT cells) develop as a subset of $\alpha \beta$-T cells in the thymus. The unique role of NKT cells is highlighted by their expression of NK-specific receptors, especially CD56 and Fc $\gamma$ RIII (CD16) in addition to a specialized $\alpha \beta$-TCR to detect antigens displayed by the monomorphic HLA-like molecule CD1d [55-59]. NKT cells are a highly interesting immune cell population, potentially enabling allogeneic chimeric antigen receptor (CAR)-NKT cell therapies [60]. However, in this review we focus on T and NK cell-based immunotherapies as these are the major players in the currently applied cell therapeutic approaches.

In this context, it is also important to mention that graft-versus-host-disease (GvHD) is a major complication after both stem cell transplantation and donor lymphocyte infusion (DLI), which is highly associated with the alloreactivity mediated by T cells. In contrast, NK and cytokine induced killer (CIK) cells represent attractive targets for immunotherapy without risk of GvHD [61,62]. Although the limited availability of primary NK cells from peripheral blood or umbilical cord blood preparations can be circumvented by optimized expansion protocols, other sources, such as induced pluripotent stem cells (iPSCs) or NK cell lines, have been developed [63]. In particular, the NK-92 cell line is a promising alternative due to its easy expansion and similar characteristics to primary NK cells $[64,65]$. Notably, NK-92 cells lack several inhibitory receptors, resulting in high levels of activation, but also CD16, which excludes their possible application in ADCC-based therapies [66]. Furthermore, NK-92 cells must be irradiated prior to their application due to the lymphoma 
origin of this cell line, leading to a reduced in vivo proliferative capacity. The effect of irradiation on the cytotoxic capacity of NK-92 cells is controversially discussed $[67,68]$.

\section{Cell Therapeutics: The Past, the Present and the Future}

2.1. A Historical Review of the Development of Cell Therapeutics

\subsubsection{Lymphokine-Activated Killer (LAK) Cells}

At the beginning of the 1980s, the group of Steven Rosenberg first described a novel approach to generate another type of cytotoxic effector cells for adoptive immunotherapy: lymphokine-activated killer (LAK) cells [69,70]. LAK cells were generated from freshly isolated peripheral blood mononuclear cells (PBMCs) that were cultured in the presence of interleukin-2 (IL-2) and were further characterized by their ability to kill NK-resistant human tumor cells, even though most LAK cells express NK markers (Figure 2) [71]. Today, it is a known fact that LAK cells are composed of a large number of NK and T cells. A huge milestone in the development of LAK-based immunotherapy as well as other immunotherapeutic fields was the isolation of human IL-2 cDNA from the Jurkat cell line in 1983 [72]. The first studies in murine tumor models revealed that administration of LAK cells alone did not lead to reduced growth of pulmonary metastases, while simultaneous administration of LAK cells and IL-2 resulted in a significant reduction in established pulmonary sarcoma metastases [73-75]. In 1985, Steven Rosenberg and colleagues demonstrated the safe administration of LAK cells for patients with metastatic melanoma refractory to standard therapies in a phase I trial [76]. However, in later phase II and III clinical trials comparing the use of IL-2 therapy alone or in combination with LAK cells, no beneficial impact of LAK cells on the patient's outcome could be observed [76,77]. Due to the low inherent cytotoxic activity of LAK cells, the need for large numbers of cells and the severe side effects that can result from the administration of IL-2, the development of LAK cell-based protocols was not pursued any further, but replaced by more specific immune cell therapies [75].

\subsubsection{T Cells}

In 1986, Rosenberg and colleagues described the cytotoxic potential of IL-2 expanded tumor-infiltrating lymphocytes (TILs), recognizing tumor-associated antigens from resected tumors in mice [78]. This discovery of the high cytotoxic potency of TILs was followed up in 1988 by the first phase I trial investigating autologous TILs in combination with IL-2-administration [79]. Here, lymphocytes could be successfully isolated from resected melanomas, followed by in vitro expansion of TILs using IL-2 and confirmation of the specific lysis of autologous tumor cells (Figure 2). After initial treatment with chemotherapy, the patients bearing metastatic melanoma were treated by administration of IL-2 and TILs. Although adoptive cell therapy (ACT) using TILs resulted in regression of cancer for several months, the treatment with IL-2 led to toxic side effects [79].

Two years later, Kolb and colleagues reported the first DLI in a phase I trial with three patients suffering from recurrent chronic myeloid leukemia (CML) [80]. Following bone marrow transplantation, lymphocytes from blood of the allogeneic donor were isolated and administered to the patients in combination with interferon $\alpha$ (IFN- $\alpha$ ), which resulted in transient cytogenetic remission [80]. Furthermore in 1994, O'Reilly and colleagues achieved complete responses in patients suffering from Epstein-Barr virus (EBV)-associated posttransplant lymphoproliferative diseases (PTLD) after chemotherapy and allogeneic T cell depleted bone marrow transplantation by administration of fresh donor lymphocytes [81]. Based on this idea, prevention of PTLD in addition to tumor regression was demonstrated shortly thereafter $[82,83]$. 


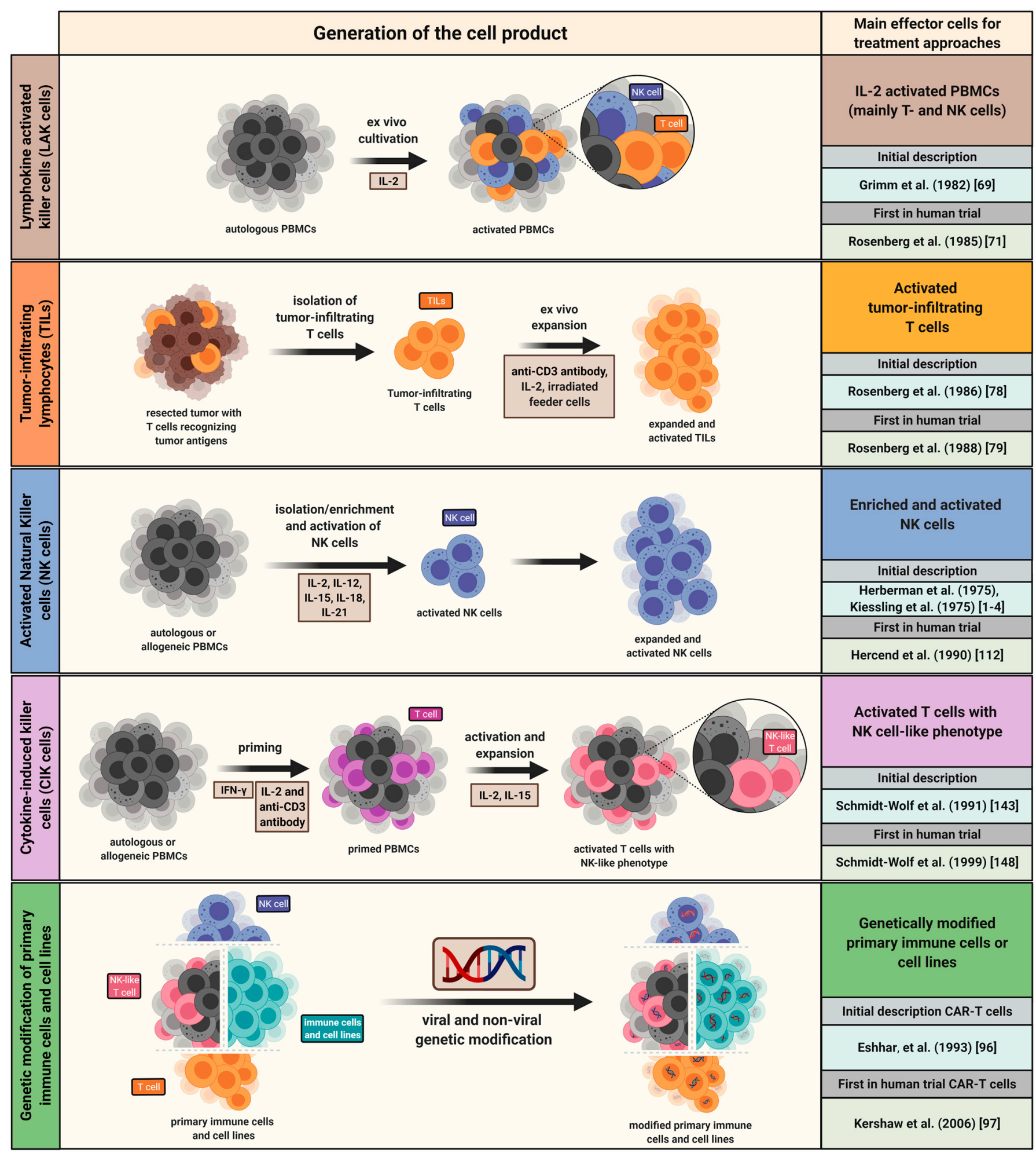

Figure 2. Generation of immune cell products for application in cancer therapy. Overview of exemplary cell sources and procedures for the generation of representative immune cell products. Additionally, time points of discovery and initial application in clinical trials are indicated. Alternative cell sources are possible for specific immune cell products. INF- $\gamma=$ Interferon- $\gamma$; PBMC $=$ peripheral blood mononuclear cells.

In parallel to DLI- and TIL-based immunotherapies, the characterization of TCRheterodimers recognizing tumor antigens and the development of chimeric antigen receptors (CARs) marked the next steps for tumor-targeting with genetically engineered $\mathrm{T}$ 
lymphocytes (Figure 2) [84-88] (for review also see Sadelain et al. [89]). The introduction of genetically modified immune cells has significantly influenced the immunotherapeutic research for the next decades to come. First, the redirection of $\mathrm{T}$ cell specificity by gene transfer of the TCR $\alpha / \beta$ chain could be successfully demonstrated for transgenic mice in 1986 [90]. However, it took a while until the first reports appeared describing an efficient transfer of melanoma-specific TCRs to human peripheral blood lymphocytes, which led to an increased antigen-specific HLA-A2-restricted CTL response [84,91]. While the introduction of preselected TCR genes into autologous $\mathrm{T}$ cells enabled a highly efficient tumor-specific CTL-response, it is important to note that such TCR-mediated antigen recognition is HLA-restricted. Furthermore, generation and optimization of novel, "non-natural" TCRs by structure guided design and affinity maturation allowed the implementation of enhanced TCRs against different tumor entities. However, the HLA-restricted targetrecognition remained a hurdle due to MHC-specificity, on-target/off-tumor toxicity and tumor escape mechanisms, such as MHC-downregulation [92-95].

Therefore, another important milestone was the generation of antigen-specific CTLhybridoma redirected by a single chain variable fragment $(\mathrm{scFv})$-based chimeric molecule that acted in a HLA-independent manner [96]. Based on this finding, Eshhar and colleagues developed the first generation of a CAR construct which carried the antigen-binding domain of a Neu/Her2 antibody as an extracellular domain and an intracellular CD3 signaling domain to promote the MHC-independent recognition pathway for T cells and an effective elimination of adenocarcinoma cells upon interaction with the target antigen [88]. Although the first-generation CARs had revealed promising results during preclinical assessment, they demonstrated only limited cytotoxic efficacy and persistence in vivo during clinical trials [97]. In order to further improve the functionality of the CAR constructs, a second-generation CAR was equipped with an additional CD28 costimulatory domain in 2002 [98]. Two years later, a second-generation CAR based on the 4-1BB costimulatory domain was published [99]. Both CAR designs proved an increased proliferation capacity and excellent cytotoxic potency of retrovirally transduced CAR-T cells [98,99].These findings promoted the application of CD19-CAR-T cells in the first successful phase I trial for treatment of chronic lymphoblastic leukemia (CLL) in 2011 [100]. Shortly thereafter, CD19-CAR-T cell therapy trials were conducted in three centers for treatment of relapsed childhood and adult acute lymphoblastic leukemia (ALL) and revealed an astonishing complete remission rate [101-108].

In the following years, the first third-generation CAR with two costimulatory domains in the intracellular signaling domain of the CAR was designed, along with the clinical trials testing the second-generation CD19-CARs [109]. Furthermore, in 2017, the first implementation of the clustered regularly interspaced short palindromic repeats (CRISPR) -technolgy utilizing the CRISPR-associated endonuclease 9 (Cas9) in a CD19-CAR-T cell product via the TRAC locus of T cells was successfully reported [110]. For further review of the history of adoptive T cell therapy see Leon et al. [111].

\subsubsection{Natural Killer Cells}

Some years after the initial application of LAK cells, a first feasibility trial evaluated the administration of ex vivo purified and expanded autologous NK cells in combination with continuous infusions of IL-2 in patients with metastatic renal cell carcinoma (Figure 2) [112] Further trials have investigated the transfer of autologous NK cell infusions in combination with IL-2 following conditioning with high-dose chemotherapy $[113,114]$. Even though autologous NK cell therapy has proven to be feasible, obvious antitumor effects could not be observed. It was hypothesized that the suppression of autologous NK cells might be due to the expression of self-MHC molecules on the surface of tumors, leading to the engagement of inhibitory KIRs $[113,114]$. Furthermore, IL-2 has been reported to induce the expansion of Tregs, which can either indirectly inhibit NK cell expansion by depriving NK cells of IL-2 or directly inhibit NK cell function in a transforming growth factor (TGF)$\beta$-dependent manner [115,116]. In 2002, Ruggeri et al. showed that KIR ligand-mismatched 
hematopoietic stem cell transplantation could trigger NK cell alloreactivity $[117,118]$. These beneficial effects of KIR-mismatched NK cell-mediated alloreactivity could not be consistently confirmed in subsequent studies, possibly due to differences in the transplantation protocols differing in preconditioning regimen or source and dosing of stem cells [119]. In a pilot study, the first allogeneic NK cell products were tested following haploidentical stem cell transplantation (HSCT) [120]. Further clinical trials revealed the safety of the administration of ex vivo purified allogeneic NK cells prior to or after HSCT [121-124].

In 2005, Jeffrey Miller and colleagues investigated the first allogeneic NK cell therapy in a non-transplant setting and found that a more intensive conditioning regimen consisting of high-dose cyclophosphamide (Cy) and fludarabine (Flu) facilitates NK cell persistence and expansion in vivo, while patients receiving a lower intensity conditioning showed only transient persistence of the administered NK cells [125]. Despite the demonstration of NK cell persistence and proliferation, only moderate clinical responses have been achieved. Further clinical trials have evaluated different NK cell sources as well as different ex vivo expansion and activation protocols [8,126,127]. In 2016, Yang et al. published the results of a first clinical trial in which allogeneic NK cells from unrelated donors were transferred without prior immune suppression for treatment of malignant lymphomas and solid tumors (NCT01212341) [128,129]. Other landmark trials of adoptively transferred NK cells in a non-transplant setting were reported by Iliopoulou et al. [130], Rubnitz et al. [131] (NCT00697671, NCT00187096), Curti et al. [132] (NCT00799799) and Geller et al. [133].

In addition to the administration of autologous or allogeneic NK cell infusions, the safety and feasibility of the adoptive transfer of NK-92 cells after irradiation was assessed in patients with renal cell carcinoma, melanoma and with relapsed or refractory hematological malignancies [134-138]. NK-92 infusions have been proven to be safe with only mild toxicities for treatment of different types of cancer [138]. Based on these beneficial properties, NK-92 cells represent an option for an "off-the-shelf" good manufacturing practice( GMP)-compliant immunotherapeutic product [139,140].

At the same time, protocols were developed which aimed to generate a specialized NK cell population for adoptive immunotherapy. First, the application of tumor-primed NK cells cultivated in the presence of tumor lysates was addressed in patients with acute myeloid leukemia (AML) [141]. Another study addressed the possible antileukemic impact of memory-like natural killer cells, which were induced by pre-activation with IL-12, -15 and -18 , for treatment of AML patients. In this first-in-human phase I trial, clinical responses were seen. In addition, proliferation and expansion of memory-like NK cells following adoptive transfer could be monitored [142].

\subsubsection{Cytokine-Induced Killer (CIK) Cells}

Simultaneously to the first clinical trials investigating the safety and efficacy of autologous NK cell transfer, Schmidt-Wolf et al. described a protocol to generate cytokine-induced killer (CIK) cells and evaluated their antitumor activity in a severe combined immunodeficient (SCID) mouse/human lymphoma model [143]. In contrast to LAK cells, generated exclusively by IL-2 activation, CIK cells were generated from PBMCs that were cultured in the presence of interferon $\gamma(\mathrm{IFN}-\gamma)$, recombinant IL-2, a monoclonal antibody (mAb) against CD3 and IL-1 $\alpha$ using a cross-sectional protocol for 21 days (Figure 2). This procedure promoted a specific induction of T cells with NK cell-like phenotype (T-NK cells) as effector cells, in comparison to the heterogeneous activated lymphocyte population present in LAK cell products. CIK cells can be generated from PBMCs, leukapheresis products, bone marrow or cord blood in the presence of defined cytokines in vitro, resulting in a heterogeneous cell population. This population is characterized by $\mathrm{CD}^{+}$ $\mathrm{T}$ cells with or without the acquisition of $\mathrm{CD} 56^{+}$and by CD3 ${ }^{-} \mathrm{CD} 56^{+} \mathrm{NK}$ cells, together combining a highly proliferative and cytotoxic cell population against a broad spectrum of cancers [143-145]. The NK-like cytotoxic capacity of CIK cells besides NKp30, DNAM-1, and LFA-1 has been mainly ascribed to NKG2D, an activating NK cell receptor. In 1994, Lu and Negrin compared the antitumor effects of CIK and LAK cells in a SCID mouse model 
of human lymphoma. In vitro, LAK and CIK cells showed similar cytotoxic potential. In vivo, CIK-treated mice showed a significant prolongation of survival rates compared to LAK-treated mice $[146,147]$. In 1999, Schmidt-Wolf et al. investigated CIK cells in patients with metastatic renal cancer, colorectal cancer and lymphoma in a first phase I clinical trial [148]. In this trial, patients received autologous CIK cells that were genetically modified to express IL-2 via electroporation. Their administration was proven to be safe and without major side effects, whereas the clinical outcome was moderate. In a first phase I trial in 2005, autologous CIK cells were given to nine patients suffering from advanced Hodgkin's disease or non-Hodgkin lymphoma (NHL) [149]. The administration of the cells was safe, and only mild toxicities were observed. In a clinical trial in 2006, Jiang et al. investigated the potential benefits of combining chemotherapy and the administration of autologous CIK cells to patients with advanced gastric cancer [150]. Furthermore, it has been demonstrated that CIK cells reached a maximum with regard to the total number and cytotoxic capacity between days 14 and 21 of culture. Further studies investigated the infusion of CIK cells in combination with chemotherapy. Li et al. performed a phase II trial for patients suffering from lung cancer [151], and Niu et al. used cord blood-derived CIK cells in combination with chemotherapy for the treatment of advanced solid malignancies [152].

In 2010, the international registry of CIK cells (IRCC) was set up and identified 11 clinical trials utilizing CIK cells to date. It was retrospectively shown that nearly all trials used autologous CIK cells (10 of 11 studies) and that 384 of 426 patients showed a clinical response. Between 2008 and 2012, 180 patients were enrolled in a randomized, multicenter phase III trial investigating CIK cell therapy in combination with chemotherapy in newly diagnosed glioblastoma patients [153]. Overall, CIK cell infusions were well tolerated with only minor side effects and CIK cell-treated patients showed a significantly higher disease-free survival rate than the untreated control group.

Further attempts to improve the antitumoral activity and to shorten the in vitro expansion period of CIK cells included the addition of IL-15 on day four of culture [154]. After 10 days, IL-15-stimulated CIK cells showed enhanced killing of AML and lymphoma cell lines as well as primary acute myeloid and lymphoblastic leukemia cells in vitro and to a certain extent improved efficacy of CIK cell therapy compared to conventional DLI in patients with relapsing hematological malignancies after allogeneic HSCT [155].

In 2020, Zhang and Schmidt-Wolf provided a 10-year update of the international registry on CIK cells in cancer immunotherapy, and identified 106 clinical trials including 10,255 patients, of whom 4889 patients with more than 30 tumor entities were treated with CIK cells alone or in combination with standard or novel therapy approaches. In addition to assessing the short-term benefits, they reviewed nine studies that reported a significantly improved 5-year survival rate, and another 27 trials demonstrating improved median progression-free and overall survival rates after CIK cell therapy, which underlines the promising antitumoral activity of CIK cells [156]. Furthermore, adoptive transfer of allogeneic CIK cells confers other advantages, such as the reduced risk of causing GvHD in comparison to $\mathrm{T}$ cell therapies, due to limited proliferative capacity and release of cytokines by CIK cells, such as IFN- $\gamma$, and lack of further severe side effects, which may protect against GvHD [156-158].

\subsection{Recent Clinical Studies of Immune Cell Therapy}

A multitude of clinical trials using adoptive NK and T cell therapies, in which autologous, allogeneic and immortalized cells are applied to fight various types of cancers, are currently being conducted worldwide [159].

One strategy constitutes the additional blockade of inhibitory receptors or receptor ligands, such as checkpoint inhibitors, on tumor and immune cells with mAbs [160-162]. Although several clinical trials have been investigating the effects of checkpoint inhibitors on NK and T cells, this novel strategy has yet to deliver convincing results [163,164].

Another approach is the additional treatment of patients with NK or T cell-activating cytokines in combination with an adoptive cell transfer to promote immune cell-activation, 
cytotoxicity and expansion. For NK cell-based therapies, IL-2, -12, -15, -18 and -21 have been shown to increase NK cell proliferation and cytotoxicity in preclinical studies [159].

A third strategy to increase efficacy of adoptively transferred NK or T cells is the sensitization of tumor cells towards cytotoxic immune cells by certain standard-of-care therapies. This was shown for chemotherapies, endocrine deprivation, sublethal doses of irradiation and various cytotoxic small molecules [163].

For adoptive $\mathrm{T}$ cells, over 50 active studies are currently listed on clinicaltrials.gov (accessed on 7 October 2020). Indications range from hematological malignancies such as multiple myeloma or B cell lymphomas to solid tumors such as melanoma, breast cancer and colorectal cancer. Furthermore, in some trials, adoptive T cells are administered to patients suffering from virus-induced diseases such as cytomegalovirus disease (NCT02982902, NCT03594981, and NCT04056533), which had already generated promising results in the past $[165,166]$, or coronavirus disease 2019 (COVID-19) (NCT04457726, NCT04578210 and NCT04351659).

In the field of CAR-modified T cells, hundreds (over 600) of clinical trials are currently being conducted worldwide, which mostly target hematological diseases and most recently also solid tumors. Results from clinical trials led to the approval of Kymriah ${ }^{\circledR}$ (Novartis Pharmaceuticals Corporation, Basel, Switzerland) and Yescarta ${ }^{\circledR}$ (Kite Pharma, Incoporated, Santa Monica, CA, USA) in 2017 and Tecartus ${ }^{\mathrm{TM}}$ (Kite Pharma, Incorporated, Santa Monica, CA, USA) in 2020 by the U.S. Food and Drug Administration (FDA). Among these three products, Kymriah and Yescarta were also approved by the European Medicines Agency (EMA) in 2018 [167-169]. Kymriah was approved for relapsed or refractory $(r / r) B$ cell acute lymphoblastic leukemia (B-ALL) and $\mathrm{r} / \mathrm{r}$ large $\mathrm{B}$ cell lymphomas [170], while Yescarta was approved for $r / r$ diffuse large $B$ cell lymphoma (DLBCL) as well as primary mediastinal large B cell lymphoma (PMBCL) $[169,171]$, and Tecartus was approved for $\mathrm{r} / \mathrm{r}$ mantle cell lymphoma (MCL) [172].

On clinicaltrials.gov (accessed on 07 October 2020), no recruiting phase I/II trials using LAK cells are listed at the moment. Since previous clinical studies have already shown that CIK cells are safe, even in a HLA-mismatch setting, and can significantly increase the survival rates of cancer patients, over 35 clinical trials using CIK cells are currently being conducted worldwide [104,148]. Indications include multiple types of cancers, including NHL, acute leukemia, colorectal cancer, liver cancer, breast cancer, melanoma and other types of solid tumors. In accordance with the striking success of CD19-redirected CAR-T cells [100-108], CIK cells were engineered to express chimeric receptors, such as CD19CARs to enhance their cytotoxic activity [173]. An interim update on the phase I/II clinical trial conducted in Monza and Bergamo, Italy, reported promising clinical response, safety with only grade 1 and 2 cytokine release syndrome (CRS) and persistence of CD19-CARCIK cells (ASH, 16 December 2020). In a recent study, CIK precursors were genetically modified to express CARs against the tumor-promoting antigen CD44v6 for treatment of high-grade soft-tissue sarcoma [174].

In the context of cell therapeutic approaches using primary NK cells, currently more than 30 active clinical trials are listed on clinicaltrials.gov for adoptive/allogeneic NK cell therapy as reported earlier [8]. Although these studies mainly cover participants suffering from various types of cancers, two studies for the treatment of COVID-19 patients are enlisted as well (NCT04344548 and NCT04365101). Both COVID-19 studies are based on the findings that a reduction of circulating cells and/or an exhausted phenotype of NK cells can be observed in the context of the COVID-19 disease [175].

Moreover, trials of NK cells in combination with immune checkpoint inhibitors (ICIs) have been conducted, which have included the usage of the PD-1 antibody pembrolizumab (NCT03937895). Furthermore, one trial was carried out in which allogeneic NK cells were administered in combination with the humanized GD2 antibody Hu3F8 to treat high-risk neuroblastoma (NCT02650648). In an earlier phase I study, adoptive NK cells in combination with the murine GD2 antibody m3F8 were shown to be safe and possess anti-neuroblastoma activity at higher cell doses (NCT00877110) [176]. 
Overall, in the majority of studies, patients receive adjuvant or first-line chemotherapy prior to NK cell administration, and in some trials, IL-2 is additionally administered (NCT01857934, NCT04347616, NCT02650648, NCT01823198, and NCT01700946). Earlier studies showed that IL-2 administration can cause durable antitumor activity but also increase the frequency of circulating regulatory $\mathrm{T}$ cells and can induce severe side effects such as pneumonitis $[177,178]$. In addition, adoptive NK cells were tested together with the IL-15 superagonist ALT-803, which has already been demonstrated to promote NK cell function in vitro and in vivo in patients suffering from acquired immune deficiency syndrome (AIDS) (NCT03899480) [179,180].

Following the success of CAR-T cell trials, the first CAR-NK cells tested in clinical studies were directed against CD19 for treatment of B-lineage acute lymphoblastic leukemia (ALL) (NCT00995137, NCT01974479). Both trials used a second-generation CAR and expanded NK cells in presence of irradiated and genetically modified K562 feeder cells and demonstrated safety and feasibility [8]. Another trial investigating CD19-CAR-NK cells at the M.D. Anderson Cancer Center (Houston, TX, USA) analyzed umbilical cord blood (UCB)-derived NK cells as a source for the adoptive transfer of CAR-NK cells for patients suffering from CD19-expressing B cell malignancies (NCT03056339). Out of the first 11 patients treated in this study, eight patients showed a clinical response, of whom seven had complete remission. A special feature of this trial was the incorporation of a suicide gene (inducible caspase 9) and a gene to ectopically produce IL-15 to improve the lifespan and persistence of NK cells in the patient [181]. Clinical trials with primary CAR-NK cells are much less common, with currently only 10 active trials worldwide. In addition to hematological malignancies, the effect of CAR-NK cells on other diseases, such as epithelial ovarian cancer (NCT03692637), pancreatic cancer (NCT03941457) or COVID-19 (NCT04324996) is under investigation. Although CAR-NK cells demonstrate promising results in previous and ongoing clinical trials, no CAR-NK cell product has received market approval yet $[8,181]$.

The first in-human trial of CAR-expressing NK-92 cells for treatment of patients with relapsed or refractory AML was conducted by Tang and colleagues (NCT02944162). In their trial, a third-generation CD33-CAR construct was used to generate CD33-CAR-NK-92 cells. The administration of pre-irradiated CD33-CAR-NK-92 cells was reported as safe and the engineered NK-92 cells could be detected up to one week post-infusion, whereas clear clinical efficacy could not be demonstrated [65].

Currently, 12 ongoing clinical trials are in the process of evaluating NK-92 cells for treatment of various types of cancers, such as multiple myeloma, glioblastoma and pancreatic cancer. In some of these trials, genetically modified NK-92 cells expressing CD16 and intracellular endogenous IL-2 (haNK cells) are being deployed [182], in others, NK-92 cells are being administered in combination with cytokines or highly potent super-agonists, such as IL-2/IL-15R $\alpha$ or IL-15/IL-15R $\alpha$ (ALT-803) [159,183]. Furthermore, NK-92 cells are being evaluated in combinatorial treatment approaches with a multitude of other drugs, such as checkpoint inhibitors [163]. At the moment, two studies are conducted which utilize unmodified NK-92 cells (NCT02465957 and NCT02727803) as well as two studies which deploy genetically modified CAR-NK-92 cells (NCT03940833 and NCT03383978) [8].

\subsection{Hurdles and Improvements for Immune Cell Therapy}

The peculiarity of tumor reactive lymphocytes that co-reside in vivo together with cancer cells and do not recognize and attack the malignant cells was termed the Hellström paradox [184]. Although impressive progress has been made to tackle inefficient antitumor immunity, many hurdles are still present in immunotherapy, such as immunosuppression by tumor immune escape mechanisms [185] and GvHD [186].

An interesting approach is the combination of the genetic modification of immune cells and immune checkpoint inhibitors. With the aim to minimize the systemic effect of immune checkpoint blockade (ICB) therapy, CAR-T cells were further modified to express and secrete an anti-PD-1 single-chain variable fragment for targeted and augmented CAR-T 
cell activity [187]. The promising synergistic effect of CAR-T cell therapy and ICB, which may help to overcome $\mathrm{T}$ cell exhaustion, may also come at a price. Cases were found in which, post CAR-T cell therapy, treatment with pembrolizumab had led to immunerelated adverse reactions [188]. For a conclusive evaluation of the safety of ICB post CAR-T cell therapy, more follow-up studies and case reports need to be analyzed. In order to explore the combination of CAR-T cell therapy with ICB, several other strategies have been introduced. CRISPR/Cas9 gene editing can be used to disrupt the inhibitory PD-1 axis $[189,190]$. Furthermore, CRISPR/Cas9 can be used to direct the CAR construct to a known and non-random genomic location to disrupt the endogenous TCR locus [110].

Furthermore, altered levels of pro- and anti-apoptotic proteins, such as B cell lymphoma 2 (BCL2) proteins and inhibitor of apoptosis proteins (IAP) [191,192] as well as downregulation of MHC proteins [193], recruitment of Tregs and myeloid-derived suppressor cells (MDSC) [194,195] lead to the development of an immunosuppressive tumor microenvironment (TME) [196,197]. Tumor cells do not only react by upregulation of inhibitory ligands, but also by downregulation or by shedding of activating ligands necessary for activation of cytotoxic lymphocytes [198]. A promising idea is the inhibition of NKG2Dligand shedding in combination with the development of NKG2D-CAR-NK cells [11,199]. Advantages of CAR-NK cells in immunotherapy are reviewed in Reindl et al. [8].

Although CAR-T cells specific for CD19 showed high potential antitumor efficacy against relapsed and refractory B-ALL in clinical trials, these therapies are limited to autologous settings even when they are HLA-matched. Furthermore, generation of sufficient numbers of CAR-T cells for patients suffering from severe lymphopenia is impractical. T cell application can be accompanied by adverse side effects such as CRS, GvHD and on-target off-tumor toxicity. An alternative method of cytotoxic CAR-T cell generation is the use of regulatory $\mathrm{T}$ cells. Imura and colleagues showed that by generating CD19-CARTregs, the target cells could be suppressed and not eliminated, which diminished the onset of GvHD in mice [200].

Furthermore, researchers have developed different safety strategies to overcome such hurdles in clinical CAR-T cell treatments in addition to investigating new treatments using allogeneic NK cells. One very well-characterized suicide gene is herpes simplex virus-thymidine kinase (HSV-tk) [201]. It is widely used in combination with ganciclovir (GCV) [202,203]. It is very often used to eliminate GvHD after donor lymphocyte therapy post-HSCT [204,205]. However, preclinical data demonstrated that anti-CD44v6-CAR-T cells equipped with the HSV-tk suicide gene could be eliminated after exposure to GCV in AML and multiple myeloma [206]. As T cell death is based on interference with DNA synthesis, gradual progress will need to be made, as it takes time to eliminate CAR-T cells by HSV-tk [207]. The inducible safety switch suicide gene caspase 9 (iCasp9) showed a much faster response to apoptosis of CAR-T cells after conditional administration of AP1903. In several clinical trials using iCasp9/ $\triangle$ CD19 T cells (NCT00710892) or similar constructs with iCasp9 (NCT01494103), GvHD symptoms were alleviated within $24 \mathrm{~h}$, and iCasp9 T cells were eliminated very rapidly, leading to rapid remission of GvHD and CRS $[208,209]$.

Further advantages were shown by using CARs co-expressing CD20 or truncated epidermal growth factor receptor (EGFRt). These CARs can be effectively eliminated with the therapeutic monoclonal antibodies rituximab or cetuximab [210,211]. In particular, the EGFRt-rituximab based suicide switch has been applied effectively in numerous clinical trials [212].

Regarding the ongoing investigation to resolve tumor immune evasion mechanisms (TIEM), new approaches divide the traditional CAR into two complementary parts using two distinct antigen-recognition domains (tandem CAR) or two single CAR constructs (dual CAR) [213] recognizing two different antigens, resulting in reduced antigen escape and "on-target off-tumor" toxicity and enhanced tumor specificity [214-216]. New constructs have been generated for the modulation of the tumor microenvironment by additional inducible cytokine release after $\mathrm{T}$ cell activation, which have been incorporated into so- 
called $\mathrm{T}$ cells redirected for universal cytokine killing (TRUCKs) [217]. With the aim to further optimize the antigen response and remodulate local microenvironments, novel designed synthetic notch (synNotch) receptors release intracellular transcription factors upon activation [215].

Additional split CAR technologies, such as the Adapter CAR technology (AdCAR) have been combined with other recent approaches. The AdCAR utilizes biotinylated $\mathrm{mAbs}$ as adapter molecules with a universal CAR system to regulate immune effector cell function. This allows not only universal but furthermore a combinatorial immune targeting [218,219].

Classical CAR-NK cell products show difficulties in migrating to the required location. One approach, which is also applicable to solid tumors, is the generation of transgenetically augmented CAR-NK cells (TRACKs). As a first proof-of-concept, CXCR4 was introduced into CD19-CAR-NK cells to increase their homing capacity towards bone marrow stromal cells [220].

In order to further circumvent $\mathrm{T}$ cell-related side effects, the development of allogeneic immune cell products such as primary NK cells or the NK-92 cell line is a highly interesting and promising approach. In a very recently published first clinical trial using CD19-CAR-NK cell treatment, patients showed response rates of $73 \%$, and no GvHD, CRS or neurotoxicity has been reported to date [181]. Although gene modification of immune cells through the use of viral-vectors is feasible, the GMP-grade production of viral-vectors for clinical application remains cost- and time-intensive with high safety standard requirements. As an alternative engineering system for CAR-immune cell products, non-viral alternatives gained increasing attention [8]. CD19-CAR-T cells with the Sleeping Beauty (SB) transposon/transposase system were safe, and no acute or late toxicities or GvHD were observed [221]. Compared with viral transduction, the SB method showed a significantly higher genomic integration profile using minicircle (MC) and SB mRNA compared to lentiviral integration in CD19-CAR-T cells [222]. Lower costs and reduced regulatory demands offer clear advantages for production of non-viral vector-based cell therapeutics under GMP, and successful clinical application has already been reported for CD19-CAR-CIK cells $[223,224]$. Furthermore, a SB-engineered signaling lymphocytic activation molecule (SLAM) family member 7 (SLAMF7)-specific T cell product for treatment of patients suffering from multiple myeloma is currently under investigation in a phase I/II clinical trial CARAMBA-1 (NCT04499339; EU Horizon 2020 project). Additionally, CIK cells can be CAR-redirected through lentiviral and non-viral transposon system [224], and can exert relevant ADCC upon incubation with clinical-grade mAbs due to CD16 expression $[225,226]$.

In the NK cell field, recently, the transfection of a CAR-containing PiggyBac transposon vector in combination with transposase DNA for the generation of CAR-iPSC-NK cells was reported [227], and the development of SB-engineered CAR-NK cell products is also currently under development and showed high cytotoxic efficacy in first preclinical evaluation (unpublished data from the Ullrich group, presented at the 47th EBMT Annual Meeting 2021).

\section{Summary and Conclusions}

The ever-evolving development of immune cell-based cancer therapy has been characterized by the generation of novel immune cell products, the constant discovery of new cancer-specific antigens and, furthermore, the genetic modification of immune cells to enhance and direct their functionality in vivo.

Although early in vitro experiments suggested LAK cells as a promising immunotherapeutic approach, the beneficial impact in clinical trials fell short of expectations [71,75-77]. Nonetheless, the insights into the possibilities of ACT for the treatment of cancer gave rise to various immune cell products shortly afterwards.

Further strategies were the application of DLIs, which especially in combination with IFN- $\alpha$, induced some tumor regression in addition to the prevention of PTLD [80-83]. 
However, a prominent risk of GvHD after infusion of immune cell products containing allogenic $\mathrm{T}$ cells remained.

An alternative approach involved in vitro expanded, autologous TILs recognizing tumor antigens from resected tumors. While administration of TILs with IL-2 demonstrated the specific and high cytotoxic potential of the immune cell product against the designated tumor, the application of IL-2 caused toxic side effects [78,79].

In parallel, the characterization of TCR-heterodimers recognizing tumor antigens and subsequent engineering of (non-natural) TCRs opened up the possibility to generate genetically engineered $\mathrm{T}$ lymphocytes redirected towards specific cancer entities [84-88]. In this context, it is important to note, that the HLA-restricted target-recognition through the TCR remained a prominent hurdle for $\mathrm{T}$ cell-based therapies due to prominent tumor escape mechanisms, such as MHC downregulation [84,90-95].

In order to provide an effective and HLA-independent tumor-recognition mechanism genetically engineered $\mathrm{T}$ cells were equipped with CARs, that enabled a highly specific antigen recognition utilizing scFvs instead of TCRs. Although the initial CAR generation failed to provide the desired in vivo response, later generations improved the CAR functionality, demonstrated excellent cytotoxic potency, and had long persistence in vivo. Furthermore, the development gave rise to highly-efficient expansion protocols, which eventually led to approval of multiple CAR-T cell products by the FDA and EMA [96-109,167-172]. However, the limited availability of tumor-exclusive antigens for certain tumor entities remains a hurdle for CAR-based immune cell products.

Based on the promising antitumoral activity after allogeneic ACT compared to T-cellexclusive products, CIK cells emerged as a promising immunotherapeutic strategy for treatment of a variety of cancers $[149,150,153,156-158]$. Following the clinical success of CAR-T cell products, further studies harbored the potential of CAR-based immunotherapy to enhance the cytotoxic activity of CIK cells against specific tumor antigens [173,174].

Furthermore, the development of immune cell products based on primary NK cells or the NK-92 cell line combine the highly effective naïve cytotoxic capability of NK cells with a low risk of causing GvHD and other T cell-related side effects in an allogeneic setting, for example due to their distinct cytokine profile [121-124,134-138,181,228]. This opens up the possibility to offer effective, allogeneic "off-the-shelf" immune cell products for cancer treatment $[139,140]$.

In contrast to $\mathrm{T}$ cell-products which can utilize a high clonal expansion and persisting memory $\mathrm{T}$ cell response after treatment, primary NK cells have a lowered proliferative capacity and persistence in vivo due to their cytokine-dependency [181]. This limited persistence is even more prominent for the NK-92 cell line, which has to be irradiated prior to application, resulting in a hold of cell proliferation [138].

To counteract these limitations, genetic engineering of NK cells, such as the implementation of CARs combined with the expression of endogenous cytokines, offers a promising opportunity to redirect the high cytotoxic potential towards specific tumor antigens, utilize the naïve cytotoxicity and achieve a long-term persistence in vivo $[8,181]$.

In conclusion, the developments in cell-based immunotherapy for the last four decades enabled the administration of more precise cell therapeutic therapies tailored to various cancer subtypes and opened up promising opportunities for the development of novel immunotherapeutic concepts for the fight against cancer.

Funding: The participating laboratories have been supported by the FCI and DKTK (to EU, PW, TBe), by the DFG (CRC/SFB 1292 and IRTG; to EU, TBe, LMR, NA, VS, TBo), by the German Cancer Aid (to EU, AM), the "Alfred and Angelika Gutermuth-Stiftung" (to EU), by "Menschen für Kinder e.V." (to EU) and MSNZ (to TBe).

Institutional Review Board Statement: Not applicable.

Informed Consent Statement: Not applicable.

Data Availability Statement: Not applicable. 
Acknowledgments: First of all, we thank all the patients who participated in the cited clinical trials. In addition, we apologize profoundly to all investigators whose scientific contribution and/or clinical trials could not be cited in this review article due to space limitations. All illustrated figures have been created with BioRender.com (accessed on 21 March 2021).

Conflicts of Interest: The authors declare no conflict of interest.

\section{References}

1. Kiessling, R.; Klein, E.; Wigzell, H. "Natural" killer cells in the mouse. I. Cytotoxic cells with specificity for mouse Moloney leukemia cells. Specificity and distribution according to genotype. Eur. J. Immunol. 1975, 5, 112-117. [CrossRef]

2. Kiessling, R.; Klein, E.; Pross, H.F.; Wigzell, H. "Natural" killer cells in the mouse. II. Cytotoxic cells with specificity for mouse Moloney leukemia cells. Characteristics of the killer cell. Eur. J. Immunol. 1975, 5, 117-121. [CrossRef]

3. Herberman, R.B.; Nunn, M.E.; Lavrin, D.H. Natural cytotoxic reactivity of mouse lymphoid cells against syngeneic and allogeneic tumors. I. Distribution of reactivity and specificity. Int. J. Cancer 1975, 16, 216-229. [CrossRef] [PubMed]

4. Herberman, R.B.; Nunn, M.E.; Holden, H.T.; Lavrin, D.H. Natural cytotoxic reactivity of mouse lymphoid cells against syngeneic and allogeneic tumors. II. Characterization of effector cells. Int. J. Cancer 1975, 16, 230-239. [CrossRef]

5. Cerottini, J.-C.; Brunner, K.T. Cell-Mediated Cytotoxicity, Allograft Rejection, and Tumor Immunity. In Advances in Immunology; Elsevier: Amsterdam, The Netherlands, 1974; Volume 18, pp. 67-132. [CrossRef]

6. Lanier, L.L.; Phillips, J.H.; Hackett, J.; Tutt, M.; Kumar, V. Natural killer cells: Definition of a cell type rather than a function. J. Immunol. 1986, 137, 2735-2739.

7. Kärre, K.; Ljunggren, H.G.; Piontek, G.; Kiessling, R. Selective rejection of H-2-deficient lymphoma variants suggests alternative immune defence strategy. Nat. Cell Biol. 1986, 319, 675-678. [CrossRef]

8. Reindl, L.M.; Albinger, N.; Bexte, T.; Müller, S.; Hartmann, J.; Ullrich, E. Immunotherapy with NK cells: Recent developments in gene modification open up new avenues. OncoImmunology 2020, 9, 1777651. [CrossRef]

9. Bauer, S.; Groh, V.; Wu, J.; Steinle, A.; Phillips, J.H.; Lanier, L.L.; Spies, T. Activation of NK Cells and T Cells by NKG2D, a Receptor for Stress-Inducible MICA. Science 1999, 285, 727-729. [CrossRef]

10. Lanier, L.L. Up on the tightrope: Natural killer cell activation and inhibition. Nat. Immunol. 2008, 9, 495-502. [CrossRef]

11. Lazarova, M.; Wels, W.S.; Steinle, A. Arming cytotoxic lymphocytes for cancer immunotherapy by means of the NKG2D/NKG2Dligand system. Expert Opin. Biol. Ther. 2020, 20, 1491-1501. [CrossRef]

12. Mehta, R.S.; Rezvani, K. Chimeric Antigen Receptor Expressing Natural Killer Cells for the Immunotherapy of Cancer. Front. Immunol. 2018, 9, 283. [CrossRef]

13. Paul, S.; Lal, G. The Molecular Mechanism of Natural Killer Cells Function and Its Importance in Cancer Immunotherapy. Front. Immunol. 2017, 8, 1124. [CrossRef]

14. Raulet, D.H. Missing self recognition and self tolerance of natural killer (NK) cells. Semin. Immunol. 2006, 18, 145-150. [CrossRef]

15. Raulet, D.H.; Guerra, N. Oncogenic stress sensed by the immune system: Role of natural killer cell receptors. Nat. Rev. Immunol. 2009, 9, 568-580. [CrossRef] [PubMed]

16. Ullrich, E.; Koch, J.; Cerwenka, A.; Steinle, A. New prospects on the NKG2D/NKG2DL system for oncology. OncoImmunology 2013, 2, e26097. [CrossRef]

17. Zhang, Y.; Zhang, Z. The history and advances in cancer immunotherapy: Understanding the characteristics of tumor-infiltrating immune cells and their therapeutic implications. Cell. Mol. Immunol. 2020, 17, 807-821. [CrossRef]

18. Arnon, T.I.; Lev, M.; Katz, G.; Chernobrov, Y.; Porgador, A.; Mandelboim, O. Recognition of viral hemagglutinins by NKp44 but not by NKp30. Eur. J. Immunol. 2001, 31, 2680-2689. [CrossRef]

19. Iwaszko, M.; Bogunia-Kubik, K. Clinical Significance of the HLA-E and CD94/NKG2 Interaction. Arch. Immunol. Ther. Exp. 2011, 59, 353-367. [CrossRef]

20. Smyth, M.J.; Cretney, E.; Kelly, J.M.; Westwood, J.A.; Street, S.E.; Yagita, H.; Takeda, K.; van Dommelen, S.L.; Degli-Esposti, M.A.; Hayakawa, Y. Activation of NK cell cytotoxicity. Mol. Immunol. 2005, 42, 501-510. [CrossRef]

21. Vivier, E.; Nunès, J.A.; Vély, F. Natural Killer Cell Signaling Pathways. Science 2004, 306, 1517-1519. [CrossRef]

22. Cooper, M.A.; Fehniger, T.A.; Caligiuri, M.A. The biology of human natural killer-cell subsets. Trends Immunol. 2001, 22, 633-640. [CrossRef]

23. Robertson, M.J.; Ritz, J. Biology and Clinical Relevance of Human Natural Killer Cells. Blood 1990, 76, 2421-2438. [CrossRef]

24. Vivier, E.; Tomasello, E.; Baratin, M.; Walzer, T.; Ugolini, S. Functions of natural killer cells. Nat. Immunol. 2008, 9, 503-510. [CrossRef] [PubMed]

25. Lanier, L.L.; Le, A.M.; Civin, C.I.; Loken, M.R.; Phillips, J.H. The relationship of CD16 (Leu-11) and Leu-19 (NKH-1) antigen expression on human peripheral blood NK cells and cytotoxic T lymphocytes. J. Immunol. 1986, 136, 4480-4486.

26. Moretta, A.; Bottino, C.; Vitale, M.; Pende, D.; Cantoni, C.; Mingari, M.C.; Biassoni, R.; Moretta, L. Activating Receptors and Coreceptors Involved in Human Natural Killer Cell-Mediated Cytolysis. Annu. Rev. Immunol. 2001, 19, 197-223. [CrossRef]

27. Voskoboinik, I.; Smyth, M.J.; Trapani, J.A. Perforin-mediated target-cell death and immune homeostasis. Nat. Rev. Immunol. 2006, 6, 940-952. [CrossRef]

28. Terme, M.; Chaput, N.; Combadiere, B.; Ma, A.; Ohteki, T.; Zitvogel, L. Regulatory T cells control dendritic cell/NK cell cross-talk in lymph nodes at the steady state by inhibiting CD4+ self-reactive T cells. J. Immunol. 2008, 180, 4679-4686. [CrossRef] [PubMed] 
29. Miller, J.F. Immunological Function of the Thymus. Lancet 1961, 278, 748-749. [CrossRef]

30. Miller, J.F.A.P. Analysis of the Thymus Influence in Leukæmogenesis. Nat. Cell Biol. 1961, 191, 248-249. [CrossRef]

31. Miller, J.F.A.P. Role of the Thymus in Murine Leukæmia. Nat. Cell Biol. 1959, 183, 1069. [CrossRef]

32. Miller, J.F.A.P. Fate of Subcutaneous Thymus Grafts in Thymectomized Mice inoculated with Leukæmic Filtrate. Nat. Cell Biol. 1959, 184, 1809-1810. [CrossRef] [PubMed]

33. Miller, J.F.A.P. Effect of neonatal thymectomy on the immunological responsiveness of the mouse. Proc. R. Soc. Lond. Ser. B Boil. Sci. 1962, 156, 415-428. [CrossRef]

34. Miller, J.F.A.P. The function of the thymus and its impact on modern medicine. Science 2020, 369, eaba2429. [CrossRef]

35. Vos, O.; De Vries, M.J.; Collenteur, J.C.; Van Bekkum, D.W. Transplantation of Homologous and Heterologous Lymphoid Cells in X-Irradiated and Non-irradiated Mice. J. Natl. Cancer Inst. 1959, 23, 53-73. [CrossRef]

36. Miller, J.F.A.P.; Mitchell, G.F. The Thymus and the Precursors of Antigen Reactive Cells. Nat. Cell Biol. 1967, 216, 659-663. [CrossRef]

37. Katz, D.H.; Benacerraf, B. The Regulatory Influence of Activated T Cells on B Cell Responses to Antigen. Adv. Immunol. 1972, 15, 1-94. [CrossRef]

38. Miller, J.F.A.P.; Mitchell, G.F. CELL TO CELL INTERACTION IN THE IMMUNE RESPONSE. I. Hemolysin-forming cells in neonatally thymectomized mice reconstituted with thymus or thoracic duct lymphocytes. J. Exp. Med. 1968, 128, 801-820. [CrossRef]

39. Mitchell, G.F.; Miller, J.F.A.P. CELL TO CELL INTERACTION IN THE IMMUNE RESPONSE. II. The source of hemolysin-forming cells in irradiated mice given bone marrow and thymus or thoracic duct lymphocytes. J. Exp. Med. 1968, 128, 821-837. [CrossRef]

40. Nossal, G.J.V.; Cunningham, A.; Mitchell, G.F.; Miller, J.F.A.P. Cell to Cell Interaction in the Immune Response. 3. Chromosomal Marker Analysis of Single Antibody-Forming Cells in Reconstituted, Irradiated, or Thymectomized Mice. J. Exp. Med. 1968, 128, 839-853. [CrossRef]

41. Chakraborty, A.K.; Weiss, A. Insights into the initiation of TCR signaling. Nat. Immunol. 2014, 15, 798-807. [CrossRef] [PubMed]

42. Clambey, E.T.; Davenport, B.; Kappler, J.W.; Marrack, P.; Homann, D. Molecules in medicine mini review: The $\alpha \beta$ T cell receptor. J. Mol. Med. 2014, 92, 735-741. [CrossRef]

43. Mousset, C.M.; Hobo, W.; Woestenenk, R.; Preijers, F.; Dolstra, H.; Van Der Waart, A.B. Comprehensive Phenotyping of T Cells Using Flow Cytometry. Cytom. Part. A 2019, 95, 647-654. [CrossRef] [PubMed]

44. Hadeiba, H.; Lahl, K.; Edalati, A.; Oderup, C.; Habtezion, A.; Pachynski, R.; Nguyen, L.; Ghodsi, A.; Adler, S.; Butcher, E.C. Plasmacytoid Dendritic Cells Transport Peripheral Antigens to the Thymus to Promote Central Tolerance. Immunity 2012, 36, 438-450. [CrossRef]

45. Kwan, J.; Killeen, N. CCR7 Directs the Migration of Thymocytes into the Thymic Medulla. J. Immunol. 2004, 172, 3999-4007. [CrossRef] [PubMed]

46. Levelt, C.N.; Carsetti, R.; Eichmann, K. Regulation of thymocyte development through CDII. Expression of T cell receptor beta CD3 epsilon and maturation to the CD4+8+ stage are highly correlated in individual thymocytes. J. Exp. Med. 1993, 178, 1867-1875. [CrossRef] [PubMed]

47. Lind, E.F.; Prockop, S.E.; Porritt, H.E.; Petrie, H.T. Mapping Precursor Movement through the Postnatal Thymus Reveals Specific Microenvironments Supporting Defined Stages of Early Lymphoid Development. J. Exp. Med. 2001, 194, 127-134. [CrossRef]

48. Schwarz, B.A.; Bhandoola, A. Trafficking from the bone marrow to the thymus: A prerequisite for thymopoiesis. Immunol. Rev. 2006, 209, 47-57. [CrossRef]

49. Ulges, A.; Schmitt, E.; Becker, C.; Bopp, T. Chapter One-Context- and Tissue-Specific Regulation of Immunity and Tolerance by Regulatory T Cells. In Advances in Immunology; Alt, F.W., Ed.; Academic Press: Cambridge, MA, USA, 2016; Volume 132, pp. 1-46.

50. Appay, V.; Van Lier, R.A.W.; Sallusto, F.; Roederer, M. Phenotype and function of human T lymphocyte subsets: Consensus and issues. Cytom. Part A 2008, 73, 975-983. [CrossRef] [PubMed]

51. Bassing, C.H.; Swat, W.; Alt, F.W. The Mechanism and Regulation of Chromosomal V(D)J Recombination. Cell 2002, 109, S45-S55. [CrossRef]

52. Bluestone, J.A.; Tang, Q. Treg cells—the next frontier of cell therapy. Science 2018, 362, 154-155. [CrossRef]

53. Janssen, E.M.; Droin, N.M.; Lemmens, E.E.; Pinkoski, M.J.; Bensinger, S.J.; Ehst, B.D.; Griffith, T.S.; Green, D.R.; Schoenberger, S.P. CD4+ T-cell help controls CD8+ T-cell memory via TRAIL-mediated activation-induced cell death. Nat. Cell Biol. 2005, 434, 88-93. [CrossRef]

54. Russell, J.H.; Ley, T.J. Lymphocyte-Mediated Cytotoxicity. Annu. Rev. Immunol. 2002, 20, 323-370. [CrossRef]

55. Cowan, J.E.; Jenkinson, W.E.; Anderson, G. Thymus medulla fosters generation of natural Treg cells, invariant $\gamma \delta \mathrm{T}$ cells, and invariant NKT cells: What we learn from intrathymic migration. Eur. J. Immunol. 2015, 45, 652-660. [CrossRef]

56. Gapin, L. Development of invariant natural killer T cells. Curr. Opin. Immunol. 2016, 39, 68-74. [CrossRef] [PubMed]

57. Jerud, E.S.; Bricard, G.; Porcelli, S.A. CD1d-Restricted Natural Killer T Cells: Roles in Tumor Immunosurveillance and Tolerance. Transfus. Med. Hemotherapy 2006, 33, 18-36. [CrossRef]

58. Vivier, E.; Anfossi, N. Inhibitory NK-cell receptors on T cells: Witness of the past, actors of the future. Nat. Rev. Immunol. 2004, 4, 190-198. [CrossRef]

59. Van Der Vliet, H.J.; Nishi, N.; Koezuka, Y.; Peyrat, M.A.; Von Blomberg, B.M.E.; Eertwegh, A.J.M.V.D.; Pinedo, H.M.; Giaccone, G.; Scheper, R.J. Effects of $\alpha$-galactosylceramide (KRN7000), interleukin-12 and interleukin-7 on phenotype and cytokine profile of human V $\alpha 24+\mathrm{V} \beta 11+\mathrm{T}$ cells. Immunology 1999, 98, 557-563. [CrossRef] 
60. Kriegsmann, K.; Kriegsmann, M.; Von Bergwelt-Baildon, M.; Cremer, M.; Witzens-Harig, M. NKT cells-New players in CAR cell immunotherapy? Eur. J. Haematol. 2018, 101, 750-757. [CrossRef]

61. Simonetta, F.; Alvarez, M.; Negrin, R.S. Natural Killer Cells in Graft-versus-Host-Disease after Allogeneic Hematopoietic Cell Transplantation. Front. Immunol. 2017, 8, 465. [CrossRef]

62. Terme, M.; Ullrich, E.; Delahaye, N.F.; Chaput, N.; Zitvogel, L. Natural killer cell-directed therapies: Moving from unexpected results to successful strategies. Nat. Immunol. 2008, 9, 486-494. [CrossRef]

63. Cheng, M.; Zhang, J.; Jiang, W.; Chen, Y.; Tian, Z. Natural killer cell lines in tumor immunotherapy. Front. Med. 2012, 6, 56-66. [CrossRef] [PubMed]

64. Gong, J.H.; Maki, G.; Klingemann, H.G. Characterization of a human cell line (NK-92) with phenotypical and functional characteristics of activated natural killer cells. Leukemia 1994, 8, 652-658.

65. Tang, X.; Yang, L.; Li, Z.; Nalin, A.P.; Dai, H.; Xu, T.; Yin, J.; You, F.; Zhu, M.; Shen, W.; et al. First-in-man clinical trial of CAR NK-92 cells: Safety test of CD33-CAR NK-92 cells in patients with relapsed and refractory acute myeloid leukemia. Am. J. Cancer Res. 2018, 8, 1083-1089.

66. Tonn, T.; Becker, S.; Esser, R.; Schwabe, D.; Seifried, E. Cellular Immunotherapy of Malignancies Using the Clonal Natural Killer Cell Line NK-J. Hematotherapy 2001, 10, 535-544. [CrossRef]

67. Fang, F.; Xiao, W.; Tian, Z. NK cell-based immunotherapy for cancer. Semin. Immunol. 2017, 31, 37-54. [CrossRef]

68. Montagner, I.M.; Penna, A.; Fracasso, G.; Carpanese, D.; Pietà, A.D.; Barbieri, V.; Zuccolotto, G.; Rosato, A. Anti-PSMA CAR-Engineered NK-92 Cells: An Off-the-Shelf Cell Therapy for Prostate Cancer. Cells 2020, 9, 1382. [CrossRef]

69. Grimm, E.A.; Mazumder, A.; Zhang, H.Z.; A Rosenberg, S. Lymphokine-activated killer cell phenomenon. Lysis of natural killer-resistant fresh solid tumor cells by interleukin 2-activated autologous human peripheral blood lymphocytes. J. Exp. Med. 1982, 155, 1823-1841. [CrossRef]

70. Grimm, E.A.; Ramsey, K.M.; Mazumder, A.; Wilson, D.J.; Djeu, J.Y.; Rosenberg, S.A. Lymphokine-activated killer cell phenomenon. II. Precursor phenotype is serologically distinct from peripheral T lymphocytes, memory cytotoxic thymus-derived lymphocytes, and natural killer cells. J. Exp. Med. 1983, 157, 884-897. [CrossRef]

71. Rosenberg, S. Lymphokine-activated killer cells: A new approach to immunotherapy of cancer. J. Natl. Cancer Inst. 1985, 75, 595-603. [CrossRef]

72. Taniguchi, T.; Matsui, H.; Fujita, T.; Takaoka, C.; Kashima, N.; Yoshimoto, R.; Hamuro, J. Structure and expression of a cloned cDNA for human interleukin-2. Nat. Cell Biol. 1983, 302, 305-310. [CrossRef]

73. Rosenberg, S.A. Immunotherapy of cancer by systemic administration of lymphoid cells plus interleukin-J. Boil. Response Modif. 1984, 3, 501-511.

74. Lotze, M.T.; Matory, Y.L.; Ettinghausen, S.E.; Rayner, A.A.; O Sharrow, S.; Seipp, C.A.; Custer, M.C.; Rosenberg, S.A. In vivo administration of purified human interleukin II. Half life, immunologic effects, and expansion of peripheral lymphoid cells in vivo with recombinant IL. J. Immunol. 1985, 135, 2865-2875.

75. Mule, J.; Shu, S.; Schwarz, S.; Rosenberg, S. Adoptive immunotherapy of established pulmonary metastases with LAK cells and recombinant interleukin-2. Science 1984, 225, 1487-1489. [CrossRef]

76. Law, T.M.; Motzer, R.J.; Mazumdar, M.; Sell, K.W.; Walther, P.; O'Connell, M.; Khan, A.; Vlamis, V.; Vogelzang, N.J.; Bajorin, D.F. Phase iii randomized trial of interleukin-2 with or without lymphokine-activated killer cells in the treatment of patients with advanced renal cell carcinoma. Cancer 1995, 76, 824-832. [CrossRef]

77. Margolin, K.A.; Aronson, F.R.; Sznol, M.; Atkins, M.B.; Ciobanu, N.; Fisher, R.I.; Weiss, G.R.; Doroshow, J.H.; Bar, M.H.; Hawkins, M.J.; et al. Phase II Trial of High-Dose Interleukin-2 and Lymphokine-Activated Killer Cells in Hodgkin's Disease and Non-Hodgkin's Lymphom. J. Immunother. 1991, 10, 214-220. [CrossRef]

78. Rosenberg, S.A.; Spiess, P.; LaFreniere, R. A new approach to the adoptive immunotherapy of cancer with tumor-infiltrating lymphocytes. Science 1986, 233, 1318-1321. [CrossRef] [PubMed]

79. Rosenberg, S.A.; Packard, B.S.; Aebersold, P.M.; Solomon, D.; Topalian, S.L.; Toy, S.T.; Simon, P.; Lotze, M.T.; Yang, J.C.-H.; Seipp, C.A.; et al. Use of Tumor-Infiltrating Lymphocytes and Interleukin-2 in the Immunotherapy of Patients with Metastatic Melanoma. N. Engl. J. Med. 1988, 319, 1676-1680. [CrossRef]

80. Kolb, H.; Mittermuller, J.; Clemm, C.; Holler, E.; Ledderose, G.; Brehm, G.; Heim, M.; Wilmanns, W. Donor leukocyte transfusions for treatment of recurrent chronic myelogenous leukemia in marrow transplant patients. Blood 1990, 76, 2462-2465. [CrossRef]

81. Papadopoulos, E.B.; Ladanyi, M.; Emanuel, D.; MacKinnon, S.; Boulad, F.; Carabasi, M.H.; Castro-Malaspina, H.; Childs, B.H.; Gillio, A.P.; Small, T.N.; et al. Infusions of Donor Leukocytes to Treat Epstein-Barr Virus-Associated Lymphoproliferative Disorders after Allogeneic Bone Marrow Transplantation. N. Engl. J. Med. 1994, 330, 1185-1191. [CrossRef] [PubMed]

82. Rooney, C.; Ng, C.; Loftin, S.; Smith, C.; Li, C.; Krance, R.; Brenner, M.; Heslop, H.; Rooney, C.M.; Brenner, M.K.; et al. Use of gene-modified virus-specific T lymphocytes to control Epstein-Barr-virus-related lymphoproliferation. Lancet 1995, 345, 9-13. [CrossRef]

83. Rooney, C.M.; Smith, C.A.; Ng, C.Y.; Loftin, S.K.; Sixbey, J.W.; Gan, Y.; Srivastava, D.-K.; Bowman, L.C.; Krance, R.A.; Brenner, M.K.; et al. Infusion of Cytotoxic T Cells for the Prevention and Treatment of Epstein-Barr Virus-Induced Lymphoma in Allogeneic Transplant Recipients. Blood 1998, 92, 1549-1555. [CrossRef]

84. Clay, T.M.; Custer, M.C.; Sachs, J.; Hwu, P.; Rosenberg, S.A.; I Nishimura, M. Efficient transfer of a tumor antigen-reactive TCR to human peripheral blood lymphocytes confers anti-tumor reactivity. J. Immunol. 1999, 163, 507-513. [PubMed] 
85. Cole, D.J.; Weil, D.P.; Shilyansky, J.; Custer, M.; Kawakami, Y.; Rosenberg, S.A.; Nishimura, M.I. Characterization of the functional specificity of a cloned T-cell receptor heterodimer recognizing the MART-1 melanoma antigen. Cancer Res. 1995, 55, 748-752.

86. Hughes, M.S.; Yu, Y.Y.; Dudley, M.E.; Zheng, Z.; Robbins, P.F.; Li, Y.; Wunderlich, J.; Hawley, R.G.; Moayeri, M.; Rosenberg, S.A.; et al. Transfer of a TCR Gene Derived from a Patient with a Marked Antitumor Response Conveys Highly Active T-Cell Effector Functions. Hum. Gene Ther. 2005, 16, 457-472. [CrossRef]

87. Morgan, R.A.; Dudley, M.E.; Yu, Y.Y.L.; Zheng, Z.; Robbins, P.F.; Theoret, M.R.; Wunderlich, J.R.; Hughes, M.S.; Restifo, N.P.; Rosenberg, S.A. High Efficiency TCR Gene Transfer into Primary Human Lymphocytes Affords Avid Recognition of Melanoma Tumor Antigen Glycoprotein 100 and Does Not Alter the Recognition of Autologous Melanoma Antigens. J. Immunol. 2003, 171, 3287-3295. [CrossRef]

88. Stancovski, I.; Schindler, D.G.; Waks, T.; Yarden, Y.; Sela, M.; Eshhar, Z. Targeting of T lymphocytes to Neu/HER2-expressing cells using chimeric single chain Fv receptors. J. Immunol. 1993, 151, 6577-6582. [PubMed]

89. Sadelain, M.; Rivière, I.; Brentjens, R.J. Targeting tumours with genetically enhanced T lymphocytes. Nat. Rev. Cancer 2003, 3 , 35-45. [CrossRef]

90. Dembić, Z.; Haas, W.; Weiss, S.; McCubrey, J.A.; Kiefer, H.; Von Boehmer, H.; Steinmetz, M. Transfer of specificity by murine $\alpha$ and $\beta$ T-cell receptor genes. Nat. Cell Biol. 1986, 320, 232-238. [CrossRef]

91. Stanislawski, T.; Voss, R.-H.; Lotz, C.; Sadovnikova, E.; Willemsen, R.A.; Kuball, J.; Ruppert, T.; Bolhuis, R.L.H.; Melief, C.J.; Huber, C.; et al. Circumventing tolerance to a human MDM2-derived tumor antigen by TCR gene transfer. Nat. Immunol. 2001, 2, 962-970. [CrossRef]

92. Zoete, V.; Irving, M.; Ferber, M.; Cuendet, M.; Michielin, O. Structure-Based, Rational Design of T Cell Receptors. Front. Immunol. 2013, 4, 268. [CrossRef] [PubMed]

93. Seliger, B.; Cabrerab, T.; Garridob, F.; Ferronec, S. HLA class I antigen abnormalities and immune escape by malignant cells. Semin. Cancer Biol. 2002, 12, 3-13. [CrossRef]

94. González-Galarza, F.F.; Takeshita, L.Y.; Santos, E.J.; Kempson, F.; Maia, M.H.T.; Da Silva, A.L.S.; Silva, A.L.T.E.; Ghattaoraya, G.S.; Alfirevic, A.; Jones, A.R.; et al. Allele frequency net 2015 update: New features for HLA epitopes, KIR and disease and HLA adverse drug reaction associations. Nucleic Acids Res. 2015, 43, D784-D788. [CrossRef] [PubMed]

95. Linette, G.P.; Stadtmauer, E.A.; Maus, M.V.; Rapoport, A.P.; Levine, B.L.; Emery, L.; Litzky, L.; Bagg, A.; Carreno, B.M.; Cimino, P.J.; et al. Cardiovascular toxicity and titin cross-reactivity of affinity-enhanced T cells in myeloma and melanoma. Blood 2013, 122, 863-871. [CrossRef] [PubMed]

96. Eshhar, Z.; Waks, T.; Gross, G.; Schindler, D.G. Specific activation and targeting of cytotoxic lymphocytes through chimeric single chains consisting of antibody-binding domains and the gamma or zeta subunits of the immunoglobulin and T-cell receptors. Proc. Natl. Acad. Sci. USA 1993, 90, 720-724. [CrossRef] [PubMed]

97. Kershaw, M.H.; Westwood, J.A.; Parker, L.L.; Wang, G.; Eshhar, Z.; Mavroukakis, S.A.; White, D.E.; Wunderlich, J.R.; Canevari, S.; Rogers-Freezer, L.; et al. A Phase I Study on Adoptive Immunotherapy Using Gene-Modified T Cells for Ovarian Cancer. Clin. Cancer Res. 2006, 12, 6106-6115. [CrossRef]

98. Maher, J.; Brentjens, R.J.; Gunset, G.; Rivière, I.; Sadelain, M. Human T-lymphocyte cytotoxicity and proliferation directed by a single chimeric TCR $\zeta$ /CD28 receptor. Nat. Biotechnol. 2002, 20, 70-75. [CrossRef] [PubMed]

99. Imai, C.; Mihara, K.; Andreansky, M.; Nicholson, I.C.; Pui, C.-H.; Geiger, T.L.; Campana, D. Chimeric receptors with 4-1BB signaling capacity provoke potent cytotoxicity against acute lymphoblastic leukemia. Leukemia 2004, 18, 676-684. [CrossRef]

100. Porter, D.L.; Levine, B.L.; Kalos, M.; Bagg, A.; June, C.H. Chimeric Antigen Receptor-Modified T Cells in Chronic Lymphoid Leukemia. N. Engl. J. Med. 2011, 365, 725-733. [CrossRef]

101. Brentjens, R.J.; Davila, M.L.; Riviere, I.; Park, J.; Wang, X.; Cowell, L.G.; Bartido, S.; Stefanski, J.; Taylor, C.; Olszewska, M.; et al CD19-Targeted T Cells Rapidly Induce Molecular Remissions in Adults with Chemotherapy-Refractory Acute Lymphoblastic Leukemia. Sci. Transl. Med. 2013, 5, 177ra38. [CrossRef]

102. Davila, M.L.; Riviere, I.; Wang, X.; Bartido, S.; Park, J.; Curran, K.; Chung, S.S.; Stefanski, J.; Borquez-Ojeda, O.; Olszewska, M.; et al. Efficacy and Toxicity Management of 19-28z CAR T Cell Therapy in B Cell Acute Lymphoblastic Leukemia. Sci. Transl. Med. 2014, 6, 224ra25. [CrossRef] [PubMed]

103. Grupp, S.A.; Kalos, M.; Barrett, D.; Aplenc, R.; Porter, D.L.; Rheingold, S.R.; Teachey, D.T.; Chew, A.; Hauck, B.; Wright, J.F.; et al. Chimeric Antigen Receptor-Modified T Cells for Acute Lymphoid Leukemia. N. Engl. J. Med. 2013, 368, 1509-1518. [CrossRef]

104. Lee, D.W.; Kochenderfer, J.N.; Stetler-Stevenson, M.; Cui, Y.K.; Delbrook, C.; Feldman, S.A.; Fry, T.J.; Orentas, R.; Sabatino, M.; Shah, N.N.; et al. T cells expressing CD19 chimeric antigen receptors for acute lymphoblastic leukaemia in children and young adults: A phase 1 dose-escalation trial. Lancet 2015, 385, 517-528. [CrossRef]

105. Maude, S.L.; Frey, N.; Shaw, P.A.; Aplenc, R.; Barrett, D.M.; Bunin, N.J.; Chew, A.; Gonzalez, V.E.; Zheng, Z.; Lacey, S.F.; et al. Chimeric antigen receptor T cells for sustained remissions in leukemia. N. Engl. J. Med. 2014, 371, 1507-1517. [CrossRef] [PubMed]

106. Maude, S.L.; Laetsch, T.W.; Buechner, J.; Rives, S.; Boyer, M.; Bittencourt, H.; Bader, P.; Verneris, M.R.; Stefanski, H.E.; Myers, G.D.; et al. Tisagenlecleucel in Children and Young Adults with B-Cell Lymphoblastic Leukemia. N. Engl. J. Med. 2018, 378, 439-448. [CrossRef]

107. Park, J.H.; Rivière, I.; Gonen, M.; Wang, X.; Sénéchal, B.; Curran, K.J.; Sauter, C.; Wang, Y.; Santomasso, B.; Mead, E.; et al. Long-Term Follow-up of CD19 CAR Therapy in Acute Lymphoblastic Leukemia. N. Engl. J. Med. 2018, 378, 449-459. [CrossRef] 
108. Van Der Stegen, S.J.C.; Hamieh, M.; Sadelain, M. The pharmacology of second-generation chimeric antigen receptors. Nat. Rev. Drug Discov. 2015, 14, 499-509. [CrossRef] [PubMed]

109. Zhong, X.-S.; Matsushita, M.; Plotkin, J.; Riviere, I.; Sadelain, M. Chimeric Antigen Receptors Combining 4-1BB and CD28 Signaling Domains Augment PI3kinase/AKT/Bcl-XL Activation and CD8+ T Cell-mediated Tumor Eradication. Mol. Ther. 2010, 18, 413-420. [CrossRef]

110. Eyquem, J.; Mansilla-Soto, J.; Giavridis, T.; Van Der Stegen, S.J.C.; Hamieh, M.; Cunanan, K.M.; Odak, A.; Gönen, K.M.C.M.; Sadelain, M. Targeting a CAR to the TRAC locus with CRISPR/Cas9 enhances tumour rejection. Nat. Cell Biol. 2017, 543, 113-117. [CrossRef]

111. Leon, E.; Ranganathan, R.; Savoldo, B. Adoptive T cell therapy: Boosting the immune system to fight cancer. Semin. Immunol. 2020, 49, 101437. [CrossRef]

112. Hercend, T.; Farace, F.; Baume, D.; Charpentier, F.; Droz, J.P.; Triebel, F.; Escudier, B. Immunotherapy with lymphokine-activated natural killer cells and recombinant interleukin-2: A feasibility trial in metastatic renal cell carcinoma. J. Boil. Response Modif. 1990, 9, 546-555.

113. Miller, J.S.; Tessmer-Tuck, J.; Pierson, B.A.; Weisdorf, D.; McGlave, P.; Blazar, B.R.; Katsanis, E.; Verfaillie, C.; Lebkowski, J.; Radford, J.; et al. Low dose subcutaneous interleukin-2 after autologous transplantation generates sustained in vivo natural killer cell activity. Biol. Blood Marrow Transpl. 1997, 3, 34-44.

114. Burns, L.J.; Weisdorf, D.J.; DeFor, T.E.; Vesole, D.H.; Repka, T.L.; Blazar, B.R.; Burger, S.R.; Panoskaltsismortari, A.; Keevertaylor, C.A.; Zhang, M.-J.; et al. IL-2-based immunotherapy after autologous transplantation for lymphoma and breast cancer induces immune activation and cytokine release: A phase I/II trial. Bone Marrow Transpl. 2003, 32, 177-186. [CrossRef]

115. Gasteiger, G.; Hemmers, S.; Firth, M.A.; Le Floc'H, A.; Huse, M.; Sun, J.C.; Rudensky, A.Y. IL-2-dependent tuning of NK cell sensitivity for target cells is controlled by regulatory T cells. J. Exp. Med. 2013, 210, 1167-1178. [CrossRef] [PubMed]

116. Ghiringhelli, F.; Ménard, C.; Terme, M.; Flament, C.; Taieb, J.; Chaput, N.; Puig, P.E.; Novault, S.; Escudier, B.; Vivier, E.; et al. CD4+CD25+ regulatory $\mathrm{T}$ cells inhibit natural killer cell functions in a transforming growth factor- $\beta$-dependent manner. J. Exp. Med. 2005, 202, 1075-1085. [CrossRef]

117. Ruggeri, L.; Capanni, M.; Urbani, E.; Perruccio, K.; Shlomchik, W.D.; Tosti, A.; Posati, S.; Rogaia, D.; Frassoni, F.; Aversa, F.; et al. Effectiveness of Donor Natural Killer Cell Alloreactivity in Mismatched Hematopoietic Transplants. Science 2002, 295, 2097-2100. [CrossRef] [PubMed]

118. Ruggeri, L.; Capanni, M.; Casucci, M.; Volpi, I.; Tosti, A.; Perruccio, K.; Urbani, E.; Negrin, R.S.; Martelli, M.F.; Velardi, A. Role of Natural Killer Cell Alloreactivity in HLA-Mismatched Hematopoietic Stem Cell Transplantation. Blood 1999, 94, 333-339. [CrossRef]

119. Farag, S.S.; Bacigalupo, A.; Eapen, M.; Hurley, C.; Dupont, B.; Caligiuri, M.A.; Boudreau, C.; Nelson, G.; Oudshoorn, M.; Van Rood, J.; et al. The Effect of KIR Ligand Incompatibility on the Outcome of Unrelated Donor Transplantation: A Report from the Center for International Blood and Marrow Transplant Research, the European Blood and Marrow Transplant Registry, and the Dutch Registry. Biol. Blood Marrow Transpl. 2006, 12, 876-884. [CrossRef]

120. Passweg, J.R.; Tichelli, A.; Meyer-Monard, S.; Heim, D.; Stern, M.; Kühne, T.; Favre, G.; Gratwohl, A. Purified donor NK-lymphocyte infusion to consolidate engraftment after haploidentical stem cell transplantation. Leukemia 2004, 18, 1835-1838. [CrossRef]

121. Koehl, U.; Esser, R.; Zimmermann, S.; Tonn, T.; Kotchetkov, R.; Bartling, T.; Sörensen, J.; Grüttner, H.-P.; Bader, P.; Seifried, E.; et al. Ex vivo Expansion of Highly Purified NK Cells for Immunotherapy after Haploidentical Stem Cell Transplantation in Children. Klin. Pädiatrie 2005, 217, 345-350. [CrossRef]

122. Yoon, S.R.; Lee, Y.S.; Yang, S.H.; Ahn, K.H.; Lee, J.-H.; Lee, J.-H.; Kim, D.Y.; Kang, Y.A.; Jeon, M.; Seol, M.; et al. Generation of donor natural killer cells from CD34+ progenitor cells and subsequent infusion after HLA-mismatched allogeneic hematopoietic cell transplantation: A feasibility study. Bone Marrow Transpl. 2009, 45, 1038-1046. [CrossRef]

123. Shi, J.; Tricot, G.; Szmania, S.; Rosen, N.; Garg, T.K.; Malaviarachchi, P.A.; Moreno, A.; Dupont, B.; Hsu, K.C.; Baxter-Lowe, L.A.; et al. Infusion of haplo-identical killer immunoglobulin-like receptor ligand mismatched NK cells for relapsed myeloma in the setting of autologous stem cell transplantation. Br. J. Haematol. 2008, 143, 641-653. [CrossRef]

124. Brehm, C.; Huenecke, S.; Quaiser, A.; Esser, R.; Bremm, M.; Kloess, S.; Soerensen, J.; Kreyenberg, H.; Seidl, C.; Becker, P.S.A.; et al. IL-2 Stimulated but Not Unstimulated NK Cells Induce Selective Disappearance of Peripheral Blood Cells: Concomitant Results to a Phase I/II Study. PLoS ONE 2011, 6, e27351. [CrossRef]

125. Miller, J.S.; Soignier, Y.; Panoskaltsis-Mortari, A.; McNearney, S.A.; Yun, G.H.; Fautsch, S.K.; McKenna, D.; Le, C.; DeFor, T.E.; Burns, L.J.; et al. Successful adoptive transfer and in vivo expansion of human haploidentical NK cells in patients with cancer. Blood 2005, 105, 3051-3057. [CrossRef]

126. Bachanova, V.; Cooley, S.; DeFor, T.E.; Verneris, M.R.; Zhang, B.; McKenna, D.H.; Curtsinger, J.; Panoskaltsis-Mortari, A.; Lewis, D.; Hippen, K.; et al. Clearance of acute myeloid leukemia by haploidentical natural killer cells is improved using IL-2 diphtheria toxin fusion protein. Blood 2014, 123, 3855-3863. [CrossRef]

127. Granzin, M.; Wagner, J.; Köhl, U.; Cerwenka, A.; Huppert, V.; Ullrich, E. Shaping of Natural Killer Cell Antitumor Activity by Ex Vivo Cultivation. Front. Immunol. 2017, 8, 458. [CrossRef] 
128. Lim, O.; Lee, Y.; Chung, H.; Her, J.H.; Kang, S.M.; Jung, M.-Y.; Min, B.; Shin, H.; Kim, T.M.; Heo, D.S.; et al. GMP-Compliant, Large-Scale Expanded Allogeneic Natural Killer Cells Have Potent Cytolytic Activity against Cancer Cells In Vitro and In Vivo. PLoS ONE 2013, 8, e53611. [CrossRef]

129. Yang, Y.; Lim, O.; Kim, T.M.; Ahn, Y.-O.; Choi, H.; Chung, H.; Min, B.; Her, J.H.; Cho, S.Y.; Keam, B.; et al. Phase I Study of Random Healthy Donor-Derived Allogeneic Natural Killer Cell Therapy in Patients with Malignant Lymphoma or Advanced Solid Tumors. Cancer Immunol. Res. 2016, 4, 215-224. [CrossRef]

130. Iliopoulou, E.G.; Kountourakis, P.; Karamouzis, M.V.; Doufexis, D.; Ardavanis, A.; Baxevanis, C.N.; Rigatos, G.; Papamichail, M.; Perez, S.A. A phase I trial of adoptive transfer of allogeneic natural killer cells in patients with advanced non-small cell lung cancer. Cancer Immunol. Immunother. 2010, 59, 1781-1789. [CrossRef]

131. Rubnitz, J.E.; Inaba, H.; Ribeiro, R.C.; Pounds, S.; Rooney, B.; Bell, T.; Pui, C.-H.; Leung, W. NKAML: A Pilot Study to Determine the Safety and Feasibility of Haploidentical Natural Killer Cell Transplantation in Childhood Acute Myeloid Leukemia. J. Clin. Oncol. 2010, 28, 955-959. [CrossRef] [PubMed]

132. Curti, A.; Ruggeri, L.; D’Addio, A.; Bontadini, A.; Dan, E.; Motta, M.R.; Trabanelli, S.; Giudice, V.; Urbani, E.; Martinelli, G.; et al. Successful transfer of alloreactive haploidentical KIR ligand-mismatched natural killer cells after infusion in elderly high risk acute myeloid leukemia patients. Blood 2011, 118, 3273-3279. [CrossRef]

133. Geller, M.A.; Cooley, S.; Judson, P.L.; Ghebre, R.; Carson, L.F.; Argenta, P.A.; Jonson, A.L.; Panoskaltsis-Mortari, A.; Curtsinger, J.; McKenna, D.; et al. A phase II study of allogeneic natural killer cell therapy to treat patients with recurrent ovarian and breast cancer. Cytotherapy 2011, 13, 98-107. [CrossRef]

134. Arai, S.; Meagher, R.; Swearingen, M.; Myint, H.; Rich, E.; Martinson, J.; Klingemann, H. Infusion of the allogeneic cell line NK-92 in patients with advanced renal cell cancer or melanoma: A phase I trial. Cytotherapy 2008, 10, 625-632. [CrossRef] [PubMed]

135. Boyiadzis, M.; Agha, M.; Redner, R.L.; Sehgal, A.; Im, A.; Hou, J.-Z.; Farah, R.; Dorritie, K.A.; Raptis, A.; Lim, S.H.; et al. Phase 1 clinical trial of adoptive immunotherapy using "off-the-shelf" activated natural killer cells in patients with refractory and relapsed acute myeloid leukemia. Cytotherapy 2017, 19, 1225-1232. [CrossRef]

136. Klingemann, H.-G.; Martinson, J. Ex vivo expansion of natural killer cells for clinical applications. Cytotherapy 2004, 6, 15-22. [CrossRef]

137. Tonn, T.; Schwabe, D.; Klingemann, H.G.; Becker, S.; Esser, R.; Koehl, U.; Suttorp, M.; Seifried, E.; Ottmann, O.G.; Bug, G. Treatment of patients with advanced cancer with the natural killer cell line NK-92. Cytotherapy 2013, 15, 1563-1570. [CrossRef]

138. Williams, B.A.; Law, A.D.; Routy, B.; Denhollander, N.; Gupta, V.; Wang, X.-H.; Chaboureau, A.; Viswanathan, S.; Keating, A. A phase I trial of NK-92 cells for refractory hematological malignancies relapsing after autologous hematopoietic cell transplantation shows safety and evidence of efficacy. Oncotarget 2017, 8, 89256-89268. [CrossRef]

139. Burger, M.C.; Zhang, C.; Harter, P.N.; Romanski, A.; Strassheimer, F.; Senft, C.; Tonn, T.; Steinbach, J.P.; Wels, W.S. CAR-Engineered NK Cells for the Treatment of Glioblastoma: Turning Innate Effectors Into Precision Tools for Cancer Immunotherapy. Front. Immunol. 2019, 10, 2683. [CrossRef] [PubMed]

140. Suck, G.; Odendahl, M.; Nowakowska, P.; Seidl, C.; Wels, W.S.; Klingemann, H.G.; Tonn, T. NK-92: An 'off-the-shelf therapeutic' for adoptive natural killer cell-based cancer immunotherapy. Cancer Immunol. Immunother. 2016, 65, 485-492. [CrossRef]

141. Kottaridis, P.D.; North, J.; Tsirogianni, M.; Marden, C.; Samuel, E.R.; Jide-Banwo, S.; Grace, S.; Lowdell, M.W. Two-Stage Priming of Allogeneic Natural Killer Cells for the Treatment of Patients with Acute Myeloid Leukemia: A Phase I Trial. PLoS ONE 2015, 10, e0123416. [CrossRef] [PubMed]

142. Romee, R.; Rosario, M.; Berrien-Elliott, M.M.; Wagner, J.A.; Jewell, B.A.; Schappe, T.; Leong, J.W.; Abdel-Latif, S.; Schneider, S.E.; Willey, S.; et al. Cytokine-induced memory-like natural killer cells exhibit enhanced responses against myeloid leukemia. Sci. Transl. Med. 2016, 8, 357ra123. [CrossRef]

143. Schmidt-Wolf, I.G.; Negrin, R.S.; Kiem, H.P.; Blume, K.G.; Weissman, I.L. Use of a SCID mouse/human lymphoma model to evaluate cytokine-induced killer cells with potent antitumor cell activity. J. Exp. Med. 1991, 174, 139-149. [CrossRef]

144. Introna, M.; Correnti, F. Innovative Clinical Perspectives for CIK Cells in Cancer Patients. Int. J. Mol. Sci. 2018, 19, 358. [CrossRef]

145. Pievani, A.; Borleri, G.; Pende, D.; Moretta, L.; Rambaldi, A.; Golay, J.; Introna, M. Dual-functional capability of CD3+CD56+ CIK cells, a T-cell subset that acquires NK function and retains TCR-mediated specific cytotoxicity. Blood 2011, 118, 3301-3310. [CrossRef] [PubMed]

146. Margolin, K.A.; Negrin, R.S.; Wong, K.K.; Chatterjee, S.; Wright, C.; Forman, S.J. Cellular immunotherapy and autologous transplantation for hematologic malignancy. Immunol. Rev. 1997, 157, 231-240. [CrossRef]

147. Lu, P.H.; Negrin, R.S. A novel population of expanded human CD3+CD56+ cells derived from T cells with potent in vivo antitumor activity in mice with severe combined immunodeficiency. J. Immunol. 1994, 153, 1687-1696.

148. Schmidt-Wolf, I.G.H.; Finke, S.; Trojaneck, B.; Denkena, A.; Lefterova, P.; Schwella, N.; Heuft, H.-G.; Prange, G.; Korte, M.; Takeya, M.; et al. Phase I clinical study applying autologous immunological effector cells transfected with the interleukin-2 gene in patients with metastatic renal cancer, colorectal cancer and lymphoma. Br. J. Cancer 1999, 81, 1009-1016. [CrossRef]

149. Leemhuis, T.; Wells, S.; Scheffold, C.; Edinger, M.; Negrin, R.S. A phase I trial of autologous cytokine-induced killer cells for the treatment of relapsed Hodgkin disease and non-Hodgkin lymphoma. Biol. Blood Marrow Transpl. 2005, 11, 181-187. [CrossRef]

150. Jiang, J.; Xu, N.; Wu, C.; Deng, H.; Lu, M.; Li, M.; Xu, B.; Wu, J.; Wang, R.; Xu, J.; et al. Treatment of advanced gastric cancer by chemotherapy combined with autologous cytokine-induced killer cells. Anticancer. Res. 2006, 26, 2237-2242. 
151. Li, R.; Wang, C.; Liu, L.; Du, C.; Cao, S.; Yu, J.; Wang, S.E.; Hao, X.; Ren, X.; Li, H. Autologous cytokine-induced killer cell immunotherapy in lung cancer: A phase II clinical study. Cancer Immunol. Immunother. 2012, 61, 2125-2133. [CrossRef]

152. Niu, Q.; Wang, W.; Li, Y.; Qin, S.; Wang, Y.; Wan, G.; Guan, J.; Zhu, W. Cord blood-derived cytokine-induced killer cells biotherapy combined with second-line chemotherapy in the treatment of advanced solid malignancies. Int. Immunopharmacol. 2011, 11, 449-456. [CrossRef]

153. Kong, D.-S.; Nam, D.-H.; Kang, S.-H.; Lee, J.W.; Chang, J.-H.; Kim, J.-H.; Lim, Y.-J.; Koh, Y.-C.; Chung, Y.-G.; Kim, J.-M.; et al. Phase III randomized trial of autologous cytokine-induced killer cell immunotherapy for newly diagnosed glioblastoma in korea. Oncotarget 2017, 8, 7003-7013. [CrossRef]

154. Rettinger, E.; Kuçi, S.; Naumann, I.; Becker, P.; Kreyenberg, H.; Anzaghe, M.; Willasch, A.; Koehl, U.; Bug, G.; Ruthardt, M.; et al. The cytotoxic potential of interleukin-15-stimulated cytokine-induced killer cells against leukemia cells. Cytotherapy 2012, 14, 91-103. [CrossRef]

155. Merker, M.; Salzmann-Manrique, E.; Katzki, V.; Huenecke, S.; Bremm, M.; Bakhtiar, S.; Willasch, A.; Jarisch, A.; Soerensen, J.; Schulz, A.; et al. Clearance of Hematologic Malignancies by Allogeneic Cytokine-Induced Killer Cell or Donor Lymphocyte Infusions. Biol. Blood Marrow Transpl. 2019, 25, 1281-1292. [CrossRef]

156. Zhang, Y.; Schmidt-Wolf, I.G.H. Ten-year update of the international registry on cytokine-induced killer cells in cancer immunotherapy. J. Cell. Physiol. 2020, 235, 9291-9303. [CrossRef]

157. Introna, M.; Lussana, F.; Algarotti, A.; Gotti, E.; Valgardsdottir, R.; Micò, C.; Grassi, A.; Pavoni, C.; Ferrari, M.L.; Delaini, F.; et al. Phase II Study of Sequential Infusion of Donor Lymphocyte Infusion and Cytokine-Induced Killer Cells for Patients Relapsed after Allogeneic Hematopoietic Stem Cell Transplantation. Biol. Blood Marrow Transpl. 2017, 23, 2070-2078. [CrossRef]

158. Rettinger, E.; Huenecke, S.; Bönig, H.; Merker, M.; Jarisch, A.; Soerensen, J.; Willasch, A.; Bug, G.; Schulz, A.; Klingebiel, T.; et al. Interleukin-15-activated cytokine-induced killer cells may sustain remission in leukemia patients after allogeneic stem cell transplantation: Feasibility, safety and first insights on efficacy. Haematology 2016, 101, e153-e156. [CrossRef]

159. Hu, W.; Wang, G.; Huang, D.; Sui, M.; Xu, Y. Cancer Immunotherapy Based on Natural Killer Cells: Current Progress and New Opportunities. Front. Immunol. 2019, 10, 1205. [CrossRef]

160. Benson, D.M.; Cohen, A.D.; Jagannath, S.; Munshi, N.C.; Spitzer, G.; Hofmeister, C.C.; Efebera, Y.A.; Andre, P.; Zerbib, R.; Caligiuri, M.A. A Phase I Trial of the Anti-KIR Antibody IPH2101 and Lenalidomide in Patients with Relapsed/Refractory Multiple Myeloma. Clin. Cancer Res. 2015, 21, 4055-4061. [CrossRef]

161. Tinker, A.V.; Hirte, H.W.; Provencher, D.; Butler, M.; Ritter, H.; Tu, D.; Azim, H.A.; Paralejas, P.; Grenier, N.; Hahn, S.-A.; et al. Dose-Ranging and Cohort-Expansion Study of Monalizumab (IPH2201) in Patients with Advanced Gynecologic Malignancies: A Trial of the Canadian Cancer Trials Group (CCTG): IND221. Clin. Cancer Res. 2019, 25, 6052-6060. [CrossRef]

162. Vey, N.; Karlin, L.; Sadot-Lebouvier, S.; Broussais, F.; Berton-Rigaud, D.; Rey, J.; Charbonnier, A.; Marie, D.; André, P.; Paturel, C.; et al. A phase 1 study of lirilumab (antibody against killer immunoglobulin-like receptor antibody KIR2D.; IPH2102) in patients with solid tumors and hematologic malignancies. Oncotarget 2018, 9, 17675-17688. [CrossRef] [PubMed]

163. Franks, S.E.; Wolfson, B.; Hodge, J.W. Natural Born Killers: NK Cells in Cancer Therapy. Cancers $2020,12,2131$. [CrossRef] [PubMed]

164. Khan, M.; Arooj, S.; Wang, H. NK Cell-Based Immune Checkpoint Inhibition. Front. Immunol. 2020, 11, 167. [CrossRef]

165. Pei, X.-Y.; Zhao, X.-Y.; Chang, Y.-J.; Liu, J.; Xu, L.-P.; Wang, Y.; Zhang, X.-H.; Han, W.; Chen, Y.-H.; Huang, X.-J. CytomegalovirusSpecific T-Cell Transfer for Refractory Cytomegalovirus Infection After Haploidentical Stem Cell Transplantation: The Quantitative and Qualitative Immune Recovery for Cytomegalovirus. J. Infect. Dis. 2017, 216, 945-956. [CrossRef] [PubMed]

166. Smith, C.; Beagley, L.; Rehan, S.; Neller, M.A.; Crooks, P.; Solomon, M.; Holmes-Liew, C.-L.; Holmes, M.; McKenzie, S.C.; Hopkins, P.; et al. Autologous Adoptive T-cell Therapy for Recurrent or Drug-resistant Cytomegalovirus Complications in Solid Organ Transplant Recipients: A Single-arm Open-label Phase I Clinical Trial. Clin. Infect. Dis. 2019, 68, 632-640. [CrossRef]

167. Ali, S.; Kjeken, R.; Niederlaender, C.; Markey, G.; Saunders, T.S.; Opsata, M.; Moltu, K.; Bremnes, B.; Grønevik, E.; Muusse, M.; et al. The European Medicines Agency Review of Kymriah (Tisagenlecleucel) for the Treatment of Acute Lymphoblastic Leukemia and Diffuse Large B-Cell Lymphoma. Oncologist 2019, 25, e321-e327. [CrossRef]

168. Gilead Sciences, Inc. U.S. FDA Approves Kite's TecartusTM, the First and Only CAR T Treatment for Relapsed or Refractory Mantle Cell Lymphoma. Available online: https:/ / www.gilead.com/news-and-press (accessed on 7 October 2020).

169. European Medicines Agency. YESCARTA: Axicabtagene Ciloleucel. Available online: https://www.ema.europa.eu/ (accessed on 7 October 2020).

170. U.S. Food and Drug Administration. KYMRIAH (Tisagenlecleucel). Available online: http://www.fda.gov/ (accessed on 7 October 2020).

171. U.S. Food \& Drug Administration. YESCARTA (Axicabtagene Ciloleucel). Available online: https://www.fda.gov (accessed on 7 October 2020).

172. U.S. Food \& Drug Administration. TECARTUS (Brexucabtagene Autoleucel). Available online: https://www.fda.gov (accessed on 7 October 2020).

173. Marin, V.; Kakuda, H.; Dander, E.; Imai, C.; Campana, D.; Biondi, A.; D'Amico, G. Enhancement of the anti-leukemic activity of cytokine induced killer cells with an anti-CD19 chimeric receptor delivering a 4-1BB- $\zeta$ activating signal. Exp. Hematol. 2007, 35, 1388-1397. [CrossRef] 
174. Leuci, V.; Casucci, G.M.; Grignani, G.; Rotolo, R.; Rossotti, U.; Vigna, E.; Gammaitoni, L.; Mesiano, G.; Fiorino, E.; Donini, C.; et al. CD44v6 as innovative sarcoma target for CAR-redirected CIK cells. OncoImmunology 2018, 7, e1423167. [CrossRef]

175. Market, M.; Angka, L.; Martel, A.B.; Bastin, D.; Olanubi, O.; Tennakoon, G.; Boucher, D.M.; Ng, J.; Ardolino, M.; Auer, R.C. Flattening the COVID-19 Curve With Natural Killer Cell Based Immunotherapies. Front. Immunol. 2020, 11, 1512. [CrossRef]

176. Modak, S.; Le Luduec, J.-B.; Cheung, I.Y.; Goldman, D.A.; Ostrovnaya, I.; Doubrovina, E.; Basu, E.; Kushner, B.H.; Kramer, K.; Roberts, S.S.; et al. Adoptive immunotherapy with haploidentical natural killer cells and Anti-GD2 monoclonal antibody m3F8 for resistant neuroblastoma: Results of a phase I study. OncoImmunology 2018, 7, e1461305. [CrossRef]

177. Ahmadzadeh, M.; Rosenberg, S.A. IL-2 administration increases CD4+CD25hi Foxp3+ regulatory T cells in cancer patients. Blood 2006, 107, 2409-2414. [CrossRef]

178. Buchbinder, E.I.; Dutcher, J.P.; Daniels, G.A.; Curti, B.D.; Patel, S.P.; Holtan, S.G.; Miletello, G.P.; Fishman, M.N.; Gonzalez, R.; Clark, J.I.; et al. Therapy with high-dose Interleukin-2 (HD IL-2) in metastatic melanoma and renal cell carcinoma following PD1 or PDL1 inhibition. J. Immunother. Cancer 2019, 7, 49. [CrossRef]

179. Chu, Y.; Rosenblum, J.; Jeng, E.K.; Alter, S.; Rhode, P.R.; Lee, J.H.; Lee, D.; Wong, H.C.; Cairo, M.S. Efficiently Targeting Metastatic Osteosarcoma, Neuroblastoma and Glioblastoma with Ex-Vivo Expanded Natural Killer Cells Combined with N-803 (ALT-803, IL-15 Superagonist) and TIM-3 Blockage. Biol. Blood Marrow Transpl. 2019, 25, S336. [CrossRef]

180. Kim, P.S.; Kwilas, A.R.; Xu, W.; Alter, S.; Jeng, E.K.; Wong, H.C.; Schlom, J.; Hodge, J.W. IL-15 superagonist/IL-15R $\alpha$ Sushi-Fc fusion complex (IL-15SA/IL-15R $\alpha$ Su-Fc; ALT-803) markedly enhances specific subpopulations of NK and memory CD8+ T cells, and mediates potent anti-tumor activity against murine breast and colon carcinomas. Oncotarget 2016, 7, 16130-16145. [CrossRef]

181. Liu, E.; Marin, D.; Banerjee, P.; Macapinlac, H.A.; Thompson, P.; Basar, R.; Kerbauy, L.N.; Overman, B.; Thall, P.; Kaplan, M.; et al. Use of CAR-Transduced Natural Killer Cells in CD19-Positive Lymphoid Tumors. N. Engl. J. Med. 2020, 382, 545-553. [CrossRef]

182. Jochems, C.; Hodge, J.W.; Fantini, M.; Fujii, R.; Ii, Y.M.M.; Greiner, J.W.; Padget, M.R.; Tritsch, S.R.; Tsang, K.Y.; Campbell, K.S.; et al. An NK cell line (haNK) expressing high levels of granzyme and engineered to express the high affinity CD16 allele. Oncotarget 2016, 7, 86359-86373. [CrossRef] [PubMed]

183. Romee, R.; Cooley, S.; Berrien-Elliott, M.M.; Westervelt, P.; Verneris, M.R.; Wagner, J.E.; Weisdorf, D.J.; Blazar, B.R.; Ustun, C.; DeFor, T.E.; et al. First-in-human phase 1 clinical study of the IL-15 superagonist complex ALT-803 to treat relapse after transplantation. Blood 2018, 131, 2515-2527. [CrossRef]

184. Hellström, I.; Hellström, K.E.; Pierce, G.E.; Yang, J.P.S. Cellular and Humoral immunity to Different Types of Human Neoplasms. Nat. Cell Biol. 1968, 220, 1352-1354. [CrossRef]

185. Vinay, D.S.; Ryan, E.P.; Pawelec, G.; Talib, W.H.; Stagg, J.; Elkord, E.; Lichtor, T.; Decker, W.K.; Whelan, R.L.; Kumara, H.M.C.S.; et al. Immune evasion in cancer: Mechanistic basis and therapeutic strategies. Semin. Cancer Biol. 2015, 35, S185-S198. [CrossRef] [PubMed]

186. Macmillan, M.L.; Robin, M.; Harris, A.C.; DeFor, T.E.; Martin, P.J.; Alousi, A.M.; Ho, V.T.; Bolaños-Meade, J.; Ferrara, J.L.; Jones, R.; et al. A Refined Risk Score for Acute Graft-versus-Host Disease that Predicts Response to Initial Therapy, Survival, and Transplant-Related Mortality. Biol. Blood Marrow Transpl. 2015, 21, 761-767. [CrossRef] [PubMed]

187. Li, S.; Siriwon, N.; Zhang, X.; Yang, S.; Jin, T.; He, F.; Kim, Y.J.; Mac, J.; Lu, Z.; Wang, S.; et al. Enhanced Cancer Immunotherapy by Chimeric Antigen Receptor-Modified T Cells Engineered to Secrete Checkpoint Inhibitors. Clin. Cancer Res. 2017, 23, 6982-6992. [CrossRef]

188. Kambhampati, S.; Gray, L.; Fakhri, B.; Lo, M.; Vu, K.; Arora, S.; Kaplan, L.; Ai, W.Z.; Andreadis, C. Immune-related Adverse Events Associated With Checkpoint Inhibition in the Setting of CAR T Cell Therapy: A Case Series. Clin. Lymphoma Myeloma Leuk. 2020, 20, e118-e123. [CrossRef]

189. Hu, W.; Zi, Z.; Jin, Y.; Li, G.; Shao, K.; Cai, Q.; Ma, X.; Wei, F. CRISPR/Cas9-mediated PD-1 disruption enhances human mesothelin-targeted CAR T cell effector functions. Cancer Immunol. Immunother. 2019, 68, 365-377. [CrossRef]

190. Nakazawa, T.; Natsume, A.; Nishimura, F.; Morimoto, T.; Matsuda, R.; Nakamura, M.; Yamada, S.; Nakagawa, I.; Motoyama, Y.; Park, Y.-S.; et al. Effect of CRISPR/Cas9-Mediated PD-1-Disrupted Primary Human Third-Generation CAR-T Cells Targeting EGFRvIII on In Vitro Human Glioblastoma Cell Growth. Cells 2020, 9, 998. [CrossRef]

191. Beroukhim, R.; Mermel, C.H.; Porter, D.; Wei, G.; Raychaudhuri, S.; Donovan, J.; Barretina, J.; Boehm, J.S.; Dobson, J.; Urashima, M.; et al. The landscape of somatic copy-number alteration across human cancers. Nature 2010, 463, 899-905. [CrossRef] [PubMed]

192. Fulda, S.; Vucic, D. Targeting IAP proteins for therapeutic intervention in cancer. Nat. Rev. Drug Discov. 2012, 11, 109-124. [CrossRef]

193. Restifo, N.P.; Esquivel, F.; Kawakami, Y.; Yewdell, J.W.; Mulé, J.J.; Rosenberg, S.A.; Bennink, J.R. Identification of human cancers deficient in antigen processing. J. Exp. Med. 1993, 177, 265-272. [CrossRef]

194. Najafi, M.; Farhood, B.; Mortezaee, K. Contribution of regulatory T cells to cancer: A review. J. Cell. Physiol. 2019, 234, 7983-7993. [CrossRef]

195. Ostrand-Rosenberg, S.; Sinha, P.; Chornoguz, O.; Ecker, C. Regulating the suppressors: Apoptosis and inflammation govern the survival of tumor-induced myeloid-derived suppressor cells (MDSC). Cancer Immunol. Immunother. 2012, 61, $1319-1325$. [CrossRef] [PubMed]

196. Nakamura, K.; Smyth, M.J. Myeloid immunosuppression and immune checkpoints in the tumor microenvironment. Cell. Mol. Immunol. 2020, 17, 1-12. [CrossRef] 
197. Neo, S.Y.; Yang, Y.; Record, J.; Ma, R.; Chen, X.; Chen, Z.; Tobin, N.P.; Blake, E.; Seitz, C.; Thomas, R.; et al. CD73 immune checkpoint defines regulatory NK cells within the tumor microenvironment. J. Clin. Investig. 2020, 130, 1185-1198. [CrossRef]

198. Waldhauer, I.; Steinle, A. NK cells and cancer immunosurveillance. Oncogene 2008, 27, 5932-5943. [CrossRef]

199. De Andrade, L.F.; Kumar, S.; Luoma, A.M.; Ito, Y.; Da Silva, P.H.A.; Pan, D.; Pyrdol, J.W.; Yoon, C.H.; Wucherpfennig, K.W. Inhibition of MICA and MICB Shedding Elicits NK-Cell-Mediated Immunity against Tumors Resistant to Cytotoxic T Cells. Cancer Immunol. Res. 2020, 8, 769-780. [CrossRef] [PubMed]

200. Imura, Y.; Ando, M.; Kondo, T.; Ito, M.; Yoshimura, A. CD19-targeted CAR regulatory T cells suppress B cell pathology without GvHD. JCI Insight 2020, 5, 5. [CrossRef] [PubMed]

201. Vassaux, G.; Martin-Duque, P. Use of suicide genes for cancer gene therapy: Study of the different approaches. Expert Opin. Biol. Ther. 2004, 4, 519-530. [CrossRef] [PubMed]

202. Moolten, F.L.; Wells, J.M. Curability of Tumors Bearing Herpes Thymidine Kinase Genes Transfered by Retroviral Vectors. J. Natl. Cancer Inst. 1990, 82, 297-300. [CrossRef] [PubMed]

203. Sangro, B.; Mazzolini, G.; Ruiz, M.; Ruiz, J.; Quiroga, J.; Herrero, I.; Qian, C.; Benito, A.; Larrache, J.; Olagüe, C.; et al. A phase I clinical trial of thymidine kinase-based gene therapy in advanced hepatocellular carcinoma. Cancer Gene Ther. 2010, 17, 837-843. [CrossRef]

204. Bonini, C.; Ferrari, G.; Verzeletti, S.; Servida, P.; Zappone, E.; Ruggieri, L.; Ponzoni, M.; Rossini, S.; Mavilio, F.; Traversari, C.; et al. HSV-TK Gene Transfer into Donor Lymphocytes for Control of Allogeneic Graft-Versus-Leukemia. Science 1997, 276, 1719-1724 [CrossRef] [PubMed]

205. Ciceri, F.; Bonini, C.; Marktel, S.; Zappone, E.; Servida, P.; Bernardi, M.; Pescarollo, A.; Bondanza, A.; Peccatori, J.; Rossini, S.; et al. Antitumor effects of HSV-TK-engineered donor lymphocytes after allogeneic stem-cell transplantation. Blood 2007, 109, 4698-4707. [CrossRef]

206. Casucci, M.; Falcone, L.; Camisa, B.; Norelli, M.; Porcellini, S.; Stornaiuolo, A.; Ciceri, F.; Traversari, C.; Bordignon, C.; Bonini, C.; et al. Extracellular NGFR Spacers Allow Efficient Tracking and Enrichment of Fully Functional CAR-T Cells Co-Expressing a Suicide Gene. Front. Immunol. 2018, 9, 507. [CrossRef]

207. Tiberghien, P. Administration of herpes simplex-thymidine kinase-expressing donor T cells with a T-cell-depleted allogeneic marrow graft. Blood 2001, 97, 63-72. [CrossRef]

208. Di Stasi, A.; Tey, S.-K.; Dotti, G.; Fujita, Y.; Kennedy-Nasser, A.; Martinez, C.; Straathof, K.; Liu, E.; Durett, A.G.; Grilley, B.; et al. Inducible Apoptosis as a Safety Switch for Adoptive Cell Therapy. N. Engl. J. Med. 2011, 365, 1673-1683. [CrossRef] [PubMed]

209. Zhou, X.; Dotti, G.; Krance, R.A.; Martinez, C.A.; Naik, S.; Kamble, R.T.; Durett, A.G.; Dakhova, O.; Savoldo, B.; Di Stasi, A.; et al. Inducible caspase-9 suicide gene controls adverse effects from alloreplete T cells after haploidentical stem cell transplantation. Blood 2015, 125, 4103-4113. [CrossRef] [PubMed]

210. Griffioen, M.; Van Egmond, E.H.; Kester, M.G.; Willemze, R.; Falkenburg, J.F.; Heemskerk, M.H. Retroviral transfer of human CD20 as a suicide gene for adoptive T-cell therapy. Haematologica 2009, 94, 1316-1320. [CrossRef]

211. Paszkiewicz, P.J.; Fräßle, S.P.; Srivastava, S.; Sommermeyer, D.; Hudecek, M.; Drexler, I.; Sadelain, M.; Liu, L.; Jensen, M.C.; Riddell, S.R.; et al. Targeted antibody-mediated depletion of murine CD19 CAR T cells permanently reverses B cell aplasia. J. Clin. Investig. 2016, 126, 4262-4272. [CrossRef] [PubMed]

212. Yu, S.; Yi, M.; Qin, S.; Wu, K. Next generation chimeric antigen receptor T cells: Safety strategies to overcome toxicity. Mol. Cancer 2019, 18, 1-13. [CrossRef]

213. Grada, Z.; Hegde, M.; Byrd, T.; Shaffer, D.R.; Ghazi, A.; Brawley, V.S.; Corder, A.; Schönfeld, K.; Koch, J.; Dotti, G.; et al. TanCAR: A Novel Bispecific Chimeric Antigen Receptor for Cancer Immunotherapy. Mol. Ther. Nucleic Acids 2013,2 , e105. [CrossRef] [PubMed]

214. Qin, H.; Ramakrishna, S.; Nguyen, S.; Fountaine, T.J.; Ponduri, A.; Stetler-Stevenson, M.; Yuan, C.M.; Haso, W.; Shern, J.F.; Shah, N.N.; et al. Preclinical Development of Bivalent Chimeric Antigen Receptors Targeting Both CD19 and CD. Mol. Ther. Oncolytics 2018, 11, 127-137. [CrossRef]

215. Roybal, K.T.; Rupp, L.J.; Morsut, L.; Walker, W.J.; McNally, K.A.; Park, J.S.; Lim, W.A. Precision Tumor Recognition by T Cells With Combinatorial Antigen-Sensing Circuits. Cell 2016, 164, 770-779. [CrossRef]

216. Schneider, D.; Xiong, Y.; Wu, D.; Nölle, V.; Schmitz, S.; Haso, W.; Kaiser, A.; Dropulic, B.; Orentas, R.J. A tandem CD19/CD20 CAR lentiviral vector drives on-target and off-target antigen modulation in leukemia cell lines. J. Immunother. Cancer 2017, 5 , 42. [CrossRef]

217. Chmielewski, M.; Hombach, A.A.; Abken, H. Of CARs and TRUCKs: Chimeric antigen receptor (CAR) T cells engineered with an inducible cytokine to modulate the tumor stroma. Immunol. Rev. 2014, 257, 83-90. [CrossRef] [PubMed]

218. Grote, S.; Chan, C.-H.; Baden, C.; Huber, S.M.; Eckert, F.; Mittelstaet, J.; Kaiser, A.; Seitz, C.; Schlegel, P.; Handgretinger, R.; et al. Abstract B70: Universal adapter CAR-engineered NK-92 cells target patient-derived glioblastoma cancer stem cells. Poster Present. Proffered Abstr. 2020, 8, B70. [CrossRef]

219. Seitz, C.M.; Kieble, C.V.; Illi, C.C.; Reiter, C.S.; Grote, M.S.; Mittelstaet, J.; Lock, M.D.; Kaiser, A.; Schleicher, S.; Handgretinger, R.; et al. Combinatorial Targeting of Multiple Shared Antigens By Adapter-CAR-T Cells (aCAR-Ts) Allows Target Cell Discrimination and Specific Lysis Based on Differential Expression Profiles. Blood 2018, 132, 4543. [CrossRef]

220. Jamali, A.; Hadjati, J.; Madjd, Z.; Mirzaei, H.R.; Thalheimer, F.B.; Agarwal, S.; Bonig, H.; Ullrich, E.; Hartmann, J. Highly Efficient Generation of Transgenically Augmented CAR NK Cells Overexpressing CXCR. Front. Immunol. 2020, 11. [CrossRef] 
221. Kebriaei, P.; Singh, H.; Huls, M.H.; Figliola, M.J.; Bassett, R.; Olivares, S.; Jena, B.; Dawson, M.J.; Kumaresan, P.R.; Su, S.; et al. Phase I trials using Sleeping Beauty to generate CD19-specific CAR T cells. J. Clin. Investig. 2016, 126, 3363-3376. [CrossRef]

222. Hudecek, M.; Gogishvili, T.; Monjezi, R.; Wegner, J.; Shankar, R.; Kruesemann, C.; Miskey, C.; Ivics, Z.; Schmeer, M.; Schleef, M.; et al. Minicircle-Based Engineering of Chimeric Antigen Receptor (CAR) T Cells. Recent Results Cancer Res. 2016, 209, 37-50. [CrossRef] [PubMed]

223. Hudecek, M.; Ivics, Z. Non-viral therapeutic cell engineering with the Sleeping Beauty transposon system. Curr. Opin. Genet. Dev. 2018, 52, 100-108. [CrossRef] [PubMed]

224. Magnani, C.F.; Gaipa, G.; Belotti, D.; Matera, G.; Tettamanti, S.; Cabiati, B.; Buracchi, C.; Fazio, G.; Zaninelli, S.; Rigamonti, S.; et al. Donor-Derived CD19 CAR Cytokine Induced Killer (CIK) Cells Engineered with Sleeping Beauty Transposon for Relapsed B-Cell Acute Lymphoblastic Leukemia (B-ALL). Blood 2019, 134, 200. [CrossRef]

225. Cappuzzello, E.; Tosi, A.; Zanovello, P.; Sommaggio, R.; Rosato, A. Retargeting cytokine-induced killer cell activity by CD16 engagement with clinical-grade antibodies. OncoImmunology 2016, 5, e1199311. [CrossRef]

226. Sommaggio, R.; Cappuzzello, E.; Pietà, A.D.; Tosi, A.; Palmerini, P.; Carpanese, D.; Nicolè, L.; Rosato, A. Adoptive cell therapy of triple negative breast cancer with redirected cytokine-induced killer cells. OncoImmunology 2020, 9, 1777046. [CrossRef]

227. Li, Y.; Hermanson, D.L.; Moriarity, B.S.; Kaufman, D.S. Human iPSC-Derived Natural Killer Cells Engineered with Chimeric Antigen Receptors Enhance Anti-tumor Activity. Cell Stem Cell 2018, 23, 181-192.e5. [CrossRef]

228. Tarn, Y.; Martinson, J.; Doligosa, K.; Klingernann, H.-G. Ex vivo expansion of the highly cytotoxic human natural killer cell line NK-92 under current good manufacturing practice conditions for clinical adoptive cellular immunotherapy. Cytotherapy 2003, 5 , 259-272. [CrossRef] [PubMed] 